\title{
Trans-tail regulation of MLL4-catalyzed H3K4 methylation by H4R3 symmetric dimethylation is mediated by a tandem PHD of MLL4
}

\author{
Shilpa S. Dhar, ${ }^{1,5}$ Sung-Hun Lee, ${ }^{1,5}$ Pu-Yeh Kan, ${ }^{1}$ Philipp Voigt, ${ }^{2}$ Li Ma, ${ }^{1}$ Xiaobing Shi, ${ }^{3}$ \\ Danny Reinberg, ${ }^{2}$ and Min Gyu Lee ${ }^{1,4,6}$ \\ ${ }^{1}$ Department of Molecular and Cellular Oncology, The University of Texas MD Anderson Cancer Center, Houston, Texas 77030, \\ USA; ${ }^{2}$ Howard Hughes Medical Institute, Department of Biochemistry, New York Univeristy School of Medicine, New York, \\ New York 10016, USA; ${ }^{3}$ Department of Biochemisty and Molecular Biology, The University of Texas MD Anderson Cancer \\ Center, Houston, Texas 77030, USA; ${ }^{4}$ Cancer Biology Program, Graduate School of Biomedical Sciences, The University of Texas \\ Health Science Center at Houston, Houston, Texas 77030, USA
}

\begin{abstract}
Mixed-lineage leukemia 4 (MLL4; also called MLL2 and ALR) enzymatically generates trimethylated histone H3 Lys 4 (H3K4me3), a hallmark of gene activation. However, how MLL4-deposited H3K4me3 interplays with other histone marks in epigenetic processes remains largely unknown. Here, we show that MLL4 plays an essential role in differentiating NT2/D1 stem cells by activating differentiation-specific genes. A tandem plant homeodomain $\left(\mathrm{PHD}_{4-6}\right)$ of MLL4 recognizes unmethylated or asymmetrically dimethylated histone $\mathrm{H} 4$ Arg 3 (H4R3me0 or H4R3me2a) and is required for MLL4's nucleosomal methyltransferase activity and MLL4mediated differentiation. Kabuki syndrome mutations in $\mathbf{P H D}_{4-6}$ reduce $\mathbf{P H D}_{4-6}$ 's binding ability and MLL4's catalytic activity. PHD $_{4-6}$ 's binding strength is inhibited by H4R3 symmetric dimethylation (H4R3me2s), a gene-repressive mark. The protein arginine methyltransferase 7 (PRMT7), but not PRMT5, represses MLL4 target genes by up-regulating H4R3me2s levels and antagonizes MLL4-mediated differentiation. Consistently, PRMT7 knockdown increases MLL4-catalyzed H3K4me3 levels. During differentiation, decreased H4R3me2s levels are associated with increased H3K4me3 levels at a cohort of genes, including many HOXA and HOXB genes. These findings indicate that the trans-tail inhibition of MLL4-generated H3K4me3 by PRMT7-regulated H4R3me2s may result from H4R3me2s's interference with PHD $_{4-6}$ 's binding activity and is a novel epigenetic mechanism that underlies opposing effects of MLL4 and PRMT7 on cellular differentiation.
\end{abstract}

[Keywords: epigenetics; HOX genes; histone modification; neuronal differentiation; PHD domains; PRMT7]

Supplemental material is available for this article.

Received August 13, 2012; revised version accepted November 13, 2012.

The basic repeating structural and functional unit of eukaryotic chromatin is the nucleosome, which consists of 147 base pairs (bp) of DNA wrapped around a histone octamer (Kornberg and Lorch 1999). The nucleosome serves as the in vivo target of multiple histone-modifying enzymes that catalyze several post-translational modifications of histones. Histone modifications have been found to result in gene activation or silencing. As a well-studied modification, histone methylation is an important platform for gene regulation and can exist in a mono-, di-, or trimethylated status at specific

\footnotetext{
${ }^{5}$ These authors contributed equally to this work.

${ }^{6}$ Corresponding author

E-mail mglee@mdanderson.org

Article is online at http://www.genesdev.org/cgi/doi/10.1101/gad.203356.112.
}

histone lysines (Sims et al. 2003; Martin and Zhang 2005).

Methylated histone H3 Lys 4 (H3K4me) is highly associated with gene activation. Trimethylated H3K4 (H3K4me3) is a genome-wide mark that surrounds the transcription start sites of as much as $75 \%$ of all human genes in several different cells lines, including embryonic stem cells (Guenther et al. 2007; Pan et al. 2007; Zhao et al. 2007). H3K4me3 levels correlate with the transcriptional frequency of actively transcribed genes (Pokholok et al. 2005; Barski et al. 2007). H3K4me2 is situated near the start sites similar to $\mathrm{H} 3 \mathrm{~K} 4 \mathrm{me} 3$, whereas its subset is frequently located at regions without $\mathrm{H} 3 \mathrm{~K} 4 \mathrm{me} 3$ (Bernstein et al. 2005). H3K4me2 was also shown to be involved in inhibition of DNA methylation (Weber et al. 2007). Monomethylated H3K4 (H3K4me1) often defines enhancer 
regions, while a substantial portion of it is localized near the start sites (Heintzman et al. 2009; Visel et al. 2009).

Methylation at H3K4 is catalyzed by several methyltransferases, including mixed-lineage leukemia 1-5 (MLL1-5) and SET1 (Ruthenburg et al. 2007). Reflecting their importance in biological processes, these H3K4 modifiers undergo oncogenic fusion or are frequently mutated in clinical samples. In particular, MLL4 has been shown to acquire some missense mutations in Kabuki syndrome (a multiple malformation disorder with mental retardation) ( $\mathrm{Ng}$ et al. 2010; Hannibal et al. 2011) and harbors somatic mutations, such as deletions and nonsense mutations, in childhood medulloblastoma and lymphomas (Morin et al. 2011; Parsons et al. 2011; Pasqualucci et al. 2011).

MLL4 is a gigantic protein (5537 amino acids) that contains the catalytic domain SET, seven plant homeodomains (PHDs) with zinc fingers, an HMG (high-mobility group)-binding motif, and two FY-rich regions (Ruthenburg et al. 2007). MLL4 is present in a multiprotein complex and shares common subunits, such as ASH2L, RBBP5, and WDR5, with other MLL family members (Cho et al. 2007; Issaeva et al. 2007; Lee et al. 2007). However, what role it plays in cellular epigenetic processes and how MLL4-catalyzed H3K4me3 communicates with other histone marks have not been addressed. Thus, we sought to determine the role of MLL4 in an epigenetic process, especially cellular differentiation of stem cells. Because Kabuki syndrome and medulloblastoma are thought to be associated with neural dysregulation (Adam and Hudgins 2005; Roussel and Hatten 2011), we focused on investigating the role of MLL4 in regulating neuronal differentiation, a key process in neural development. For this, we used the human pluripotent embryonal carcinoma cell line NTERA-2 clone D1 (NT2/D1), a well-characterized model stem cell line that commits to neuronal differentiation during retinoic acid (RA) treatment (Simeone et al. 1990; Houldsworth et al. 2002).

In this study, we demonstrate that MLL4 facilitates neuronal differentiation of NT2/D1 cells by activating differentiation-specific genes, such as HOXA1-3 and NESTIN. A tandem PHD ( $\left.\mathrm{PHD}_{4-6}\right)$ of MLL4 binds to unmethylated or asymmetrically dimethylated histone $\mathrm{H} 4 \mathrm{Arg} 3$ (H4R3me0 or H4R3me2a) and is essential for MLL4's nucleosomal methylation activity and MLL4-mediated differentiation. The binding ability of the tandem PHD is reduced by symmetrically dimethylated H4R3 (H4R3me2s), a repressive mark. At MLL4 target genes, increases in MLL4-catalyzed H3K4me3 parallels decreases in H4R3me2s, whose levels are positively regulated by the protein arginine methyltransferase 7 (PRMT7). In contrast to MLL4, PRMT7 knockdown stimulates expression of MLL4 target genes and neuronal differentiation and increases MLL4-catalyzed H3K4me3 levels. Our results indicate that the trans-tail inhibition of H3K4me3 by H4R3me2s at MLL4 target genes is mediated by H4R3me2s's hindrance to $\mathrm{PHD}_{4-6}$ 's binding ability.

\section{Results}

MLL4 mediates neuronal differentiation of NT2/D1 stem cells by activating differentiation-specific genes, such as HOXA1-3 and NESTIN

To understand the role of MLL4 in an epigenetic process, we examined the effect of MLL4 knockdown on differentiation phenotypes of NT2/D1 stem cells during RA treatment. MLL4 depletion by two independent shRNAs drastically suppressed RA-induced differentiation (Fig. 1A; Supplemental Fig. 1A), uncovering a critical role for MLL4 in the neuronal lineage commitment of NT2/D1 cells. Next, we monitored the effect of MLL4 knockdown on the expression of the well-known neuronspecific gene NESTIN and the key development and differentiation genes $H O X A 1-3$ at the indicated time points. We included HOXA1-3 because MLL4's partner protein, ASH2L, was recruited to them during NT2/D1 cell differentiation (Lee et al. 2007). MLL4 knockdown inhibited RA-induced expression of HOXA1-3 and NESTIN (Fig. 1B-E), whereas it had no significant effect on the expression of the NANOG gene encoding a self-renewal factor of stem cells (Fig. 1F). These results indicate that MLL4 specifically activates the differentiation-specific genes during neuronal differentiation of NT2/D1 cells.

To assess whether MLL4 directly regulates the HOXA1-3 and NESTIN genes, we performed quantitative chromatin immunoprecipitation (qChIP) experiments. Results showed that MLL4 was recruited to these genes, indicating that HOXA1-3 and NESTIN are MLL4's direct target genes (Fig. 1G,H; Supplemental Fig. 1B,C). Moreover, MLL4 recruitment was accompanied by increased H3K4me3 levels at HOXA1-3 and NESTIN, and MLL4 knockdown significantly inhibited RA-induced increases of $\mathrm{H} 3 \mathrm{~K} 4 \mathrm{me} 3$ at these MLL4 target genes (Fig. 1G,H; Supplemental Fig. 1B,C). These results are in accordance with MLL4's role in $\mathrm{H} 3 \mathrm{~K} 4$ methylation and indicate that MLL4 plays an essential role in the neuronal differentiation of NT2/D1 cells by establishing $\mathrm{H} 3 \mathrm{~K} 4 \mathrm{me} 3$ at the differentiation-specific genes.

Because MLL3 has been shown to be copurified with MLL4 (Cho et al. 2007; Issaeva et al. 2007; Lee et al. 2007), we also determined the effect of MLL3 knockdown on HOXA1-3 and NESTIN expression in NT2/D1 cells. MLL3 depletion decreased RA-induced activation of HOXA1-3 and NESTIN but not NANOG (Supplemental Fig. 2A-F). However, the inhibitory effect of MLL3 knockdown on gene expression was weaker than that of MLL4 knockdown (cf. Fig. 1B-E and Supplemental Fig. $2 \mathrm{~B}-\mathrm{E})$. These results led us to conclude that although both MLL3 and MLL4 regulate the HOXA1-3 and NESTIN genes, MLL4 may play a dominant role in activating these genes. For this reason and because of its frequent clinical mutations, we chose to decipher the role of MLL4 (rather than MLL3) in regulating neuronal differentiation. 
A
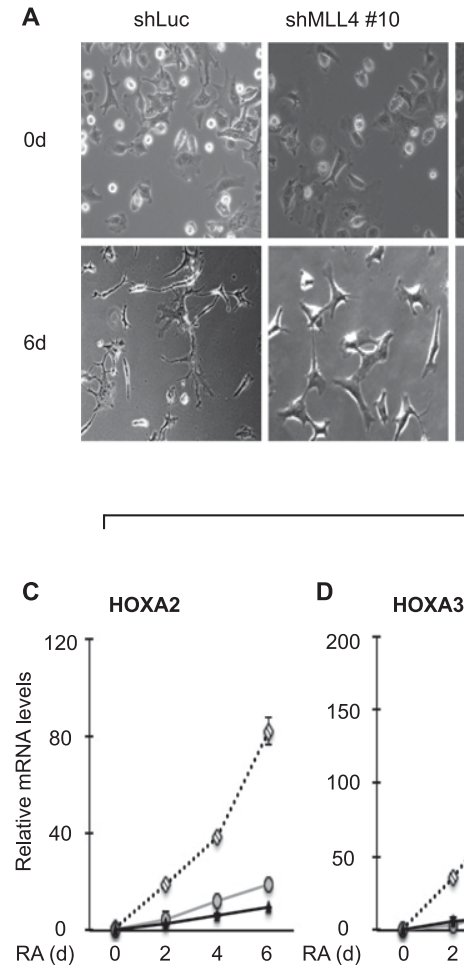

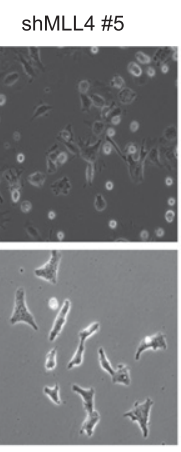

B

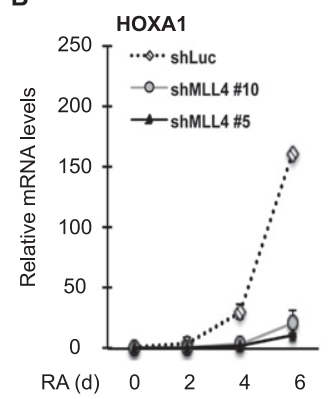

*.* shLuc

- - shMLL4 \#10 $\rightarrow$ shMLL4 \#5
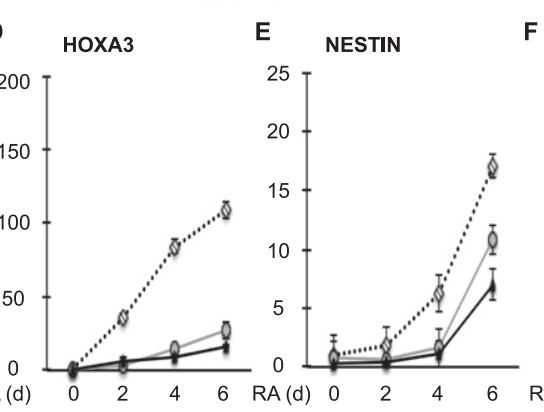

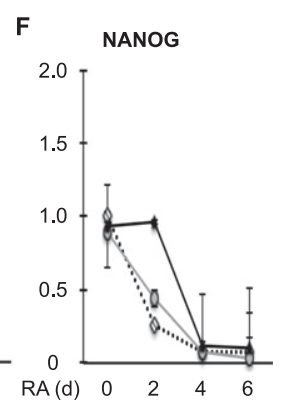

G

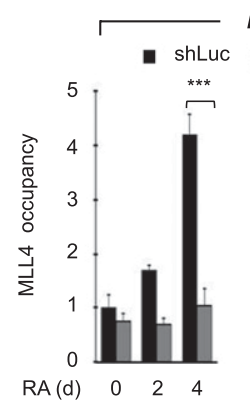

Hox

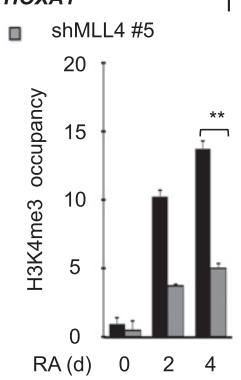

H

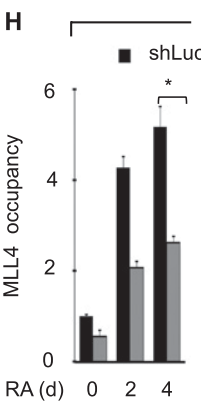

NESTIN

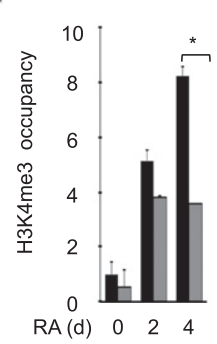

Figure 1. MLL4 knockdown impairs neuronal differentiation and expression of differentiation-specific genes. (A) Effect of shRNA-mediated knockdown of MLL4 on differentiation phenotypes of NT2/D1 cells. Three different groups (shLuciferase [shLuc], shMLL4 \#10, or shMLL4 \#5) of shRNAtreated NT2/D1 cells $\left(2 \times 10^{4}\right.$ to $\left.5 \times 10^{4}\right)$ were seeded and incubated with $10 \mu \mathrm{M}$ RA for $0 \mathrm{~d}$ (i.e., no RA treatment) and $6 \mathrm{~d}$ for neuronal differentiation. Cell differentiation patterns were monitored using a microscope $(40 \times)$; shown are representative images of three independent experiments. $(B-F)$ Effects of MLL4 knockdown on mRNA expression levels of HOXA1 $(B)$, HOXA2 $(C)$, HOXA3 $(D)$, NESTIN $(E)$, and NANOG $(F)$. shRNAtreated NT2/D1 cells were incubated with $10 \mu \mathrm{M}$ RA and harvested at the indicated time points. Total RNAs were isolated and analyzed by quantitative RT-PCR (qRT-PCR). Expression levels were normalized to $18 \mathrm{~s}$ RNA, and the relative fold change represents the expression levels in individual samples over those in shLuc-treated samples $(0 \mathrm{~d})$. Data are presented as the mean \pm SEM /error bars) of three independent experiments. $(G, H)$ Effect of MLL4 knockdown on the promoter occupancy of $\mathrm{H} 3 \mathrm{~K} 4 \mathrm{me} 3$ at the HOXA1 $(G)$ and NESTIN $(H)$ genes during RA-induced differentiation of NT2/D1 cells. Chromatin levels of MLL4 and H3K4me3 were analyzed by qChIP assay after incubating shLuc- or shMLL4 \#5-treated cells with $10 \mu \mathrm{M}$ RA for 0,2 , and $4 \mathrm{~d}$. Data are presented as the mean \pm SEM (error bars) of at least three independent experiments. $\left(^{\star}\right) P<0.05$; $\left.{ }^{\star \star \star}\right) P<0.01 ;\left(^{\star \star \star}\right) P<0.001$, statistically significant changes.
A tandem PHD domain (PHD $\left.{ }_{4-6}\right)$ of MLL4 interacts with H4R3me 0 or H4R3me2a, and its binding ability is inhibited by H4R3me2s

Several PHD domains, including PHDs in BPTF and ING2, interact with methylated or unmethylated lysines in histone H3 (Li et al. 2006; Pena et al. 2006; Shi et al. 2006; Wysocka et al. 2006; Lan et al. 2007; Musselman and Kutateladze 2011), whereas other PHDs recognize acetyl lysines (Lange et al. 2008; Zeng et al. 2010; Musselman et al. 2012). In MLL4, seven PHD domains are organized into two tandem PHDs $\left(\mathrm{PHD}_{1-3}\right.$ and $\left.\mathrm{PHD}_{4-6}\right)$ and one single $\mathrm{PHD}\left(\mathrm{PHD}_{7}\right)$ (Fig. 2A). In an effort to understand how MLL4 deposits H3K4me3, we determined whether PHDs of MLL4 serve as a chromatin-binding module and contribute to MLL4-catalyzed H3K4 methylation. We first determined whether MLL4's PHD domains have binding activities toward histone tails using three recombinant GST fusion proteins (GST-PHD ${ }_{1-3}$, GST-PHD ${ }_{4-6}$, and GST-PHD ${ }_{7}$ ) (Supplemental Fig. 3A). Our in vitro binding assays showed that only GST-PHD 4 -6 interacted with unmethylated $\mathrm{H} 4$ (H4 [amino acids 1-23]) and H4K20me peptide (Fig. 2B). Because $\mathrm{PHD}_{4-6}$ recognized the $\mathrm{H} 4$ peptides regardless of H4K20's methylation status, these results indicate that a PHD domain or domains in $\mathrm{PHD}_{4-6}$ may interact with other amino acids rather than with the 20th amino acid of the $\mathrm{H} 4$ peptides.

MLL4-mediated activation of the HOXA1-3 and NESTIN genes is repressed in undifferentiated NT2/D1 cells (see Fig. 1). Therefore, we assessed whether a repressive modification in the $\mathrm{H} 4$ tail, such as H4R3me2s, has a negative effect on $\mathrm{PHD}_{4-6}$ 's binding ability. H4R3me2s inhibited $\mathrm{PHD}_{4-6}$ 's binding ability, whereas H4R3me2a, a gene activation mark, did not (Fig. 2C; Supplemental Fig. 3B,C). These results indicate that the tandem PHD may recognize H4R3me0 and H4R3me2a.

To determine whether each PHD domain in $\mathrm{PHD}_{4-6}$ contributes to $\mathrm{PHD}_{4-6}$ 's binding ability, we purified individually $\mathrm{PHD}_{4}, \mathrm{PHD}_{5}$, and $\mathrm{PHD}_{6}$ as GST fusion proteins (Supplemental Fig. 3D). In the binding and washing 
Dhar et al.

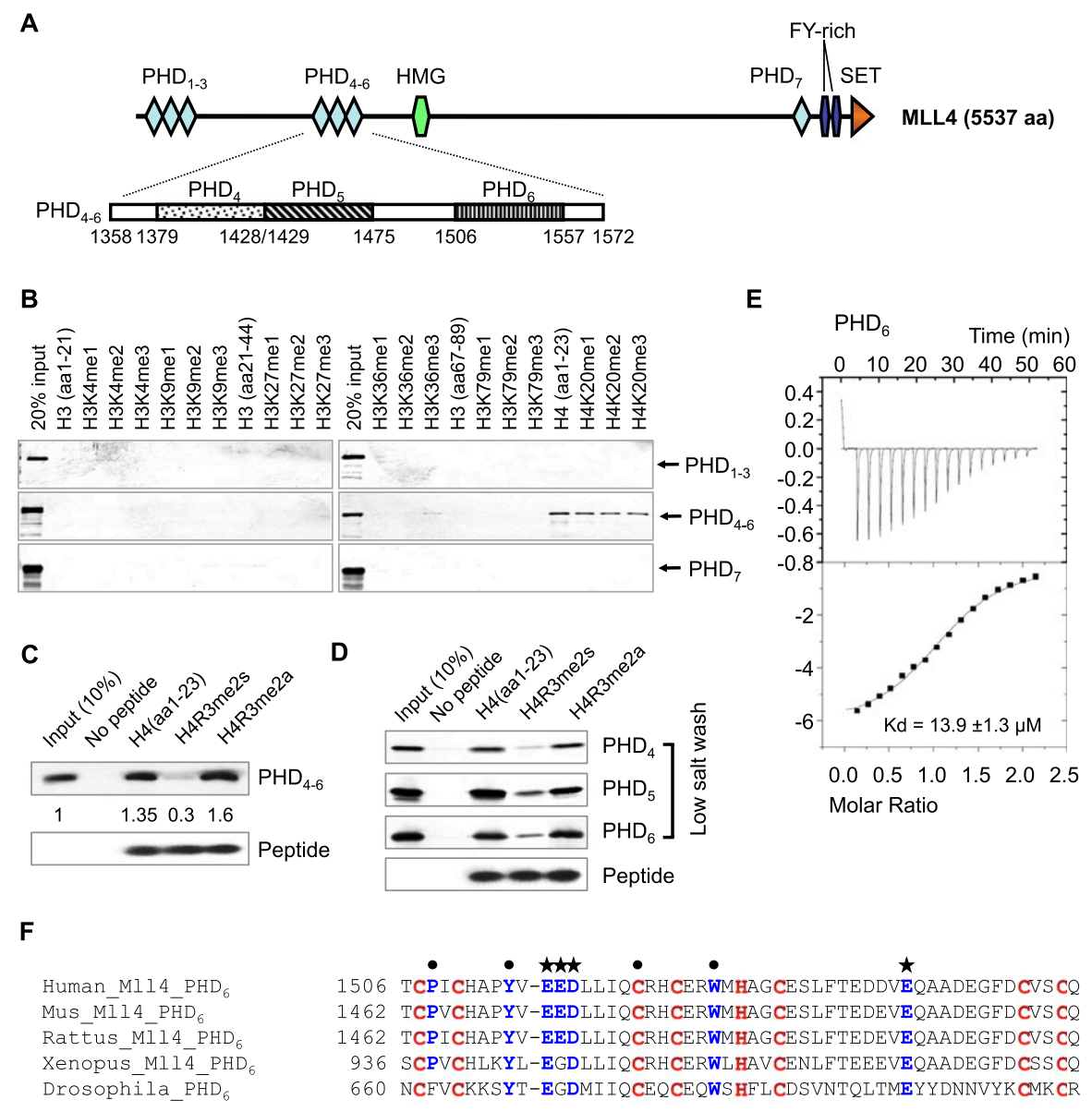

G

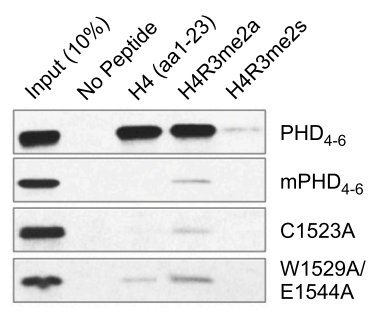

H

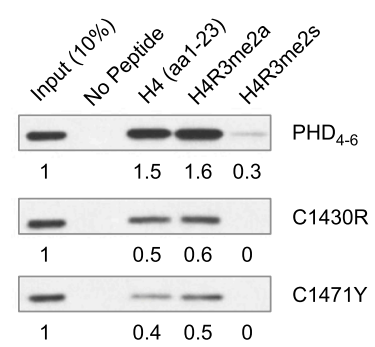

Figure 2. $\mathrm{PHD}_{4-6}$ 's binding ability to $\mathrm{H} 4 \mathrm{R} 3 \mathrm{me} 0$ or H4R3me2a is inhibited by H4R3me2s. (A) Diagrammatic representation of the domain organization of human MLL4. MLL4 contains two tandem PHD domains $\left(\mathrm{PHD}_{1-3}\right.$ and $\left.\mathrm{PHD}_{4-6}\right)$ and one $\mathrm{PHD}$ domain $\left(\mathrm{PHD}_{7}\right)$. (SET) The catalytic domain; (HMG) high-mobility group. (B) Peptide pull-down assays using the indicated biotinylated peptides and GST-tagged PHD domains. (C) Peptide pull-down assays using $0.2 \mu \mathrm{g}$ of biotinylated peptides (H4 [amino acids 1-23], H4R3me2s, and H4R3me2a) and GST-PHD -6. $_{\text {. }}(D)$ Peptide pull-down assays using $0.2 \mu \mathrm{g}$ of biotinylated peptides (H4 [amino acids 1-23], H4R3me2s, and H4R3me2a) and GST-tagged PHD proteins. Assays were performed using a low-salt wash (150 mM NaCl). (E) Analysis of the affinities of $\mathrm{PHD}_{6}$ to $\mathrm{H} 4$ amino acids 1-23) by isothermal titration calorimetry assay. (F) Sequence alignment of PHD 6 domains of MLL4 homologs among different species. The conserved $\mathrm{C}_{4} \mathrm{HC}_{3}$ motives of PHD domains and the similar type of residues are marked in bold red and bold blue, respectively. The point mutation sites in the quadruple mutant $\mathrm{mPHD}_{4-6}$ are shown by black stars (E1516A/E1517A/ D1518A/E1544A). Black circles indicate the point mutation sites in other PHD $_{4-6}$ mutants. (G) Peptide pull-down assays using the indicated $\mathrm{PHD}_{4-6}$ mutants and $0.2 \mu \mathrm{g}$ of biotinylated $\mathrm{H} 4$ (amino acids 1-23) peptide. $(H)$ Peptide pull-down assays using mutant $\mathrm{PHD}_{4-6}$ proteins (C1430R and $\mathrm{C} 1471 \mathrm{Y}$ ) and $0.2 \mu \mathrm{g}$ of the indicated peptides. For $B, C, G$, and $H$, peptide pull-down assays were carried out using a wash buffer containing $300 \mathrm{mM} \mathrm{NaCl}$. Eluates from peptide pull-down assays were examined by Western blot analysis.

condition $\left(300 \mathrm{mM} \mathrm{NaCl}\right.$ ) used for $\mathrm{PHD}_{4-6}$, none of these individual domains bound to the unmethylated $\mathrm{H} 4$ peptide (Supplemental Fig. 3E). However, in a low-salt condition $(150 \mathrm{mM} \mathrm{NaCl})$, all of them interacted with
H4R3me0 or H4R3me2a, while their binding abilities were inhibited by H4R3me2s (Fig. 2D). These results indicate that $\mathrm{PHD}_{4}, \mathrm{PHD}_{5}$, and $\mathrm{PHD}_{6}$ possess a nearly identical binding characteristic. Consistently, there are 
some sequence similarities in these PHD domains (Supplemental Fig. 3F). The isothermal calorimetry assays demonstrated that although the accurate binding constant of $\mathrm{PHD}_{4-6}$ could not be measured because of its oligomerization (data not shown), the binding strength of $\mathrm{PHD}_{4-6}$ was about threefold higher than that of $\mathrm{PHD}_{6}$ $(\mathrm{Kd}=13.9 \pm 1.3 \mu \mathrm{M})$ (Fig. 2E). Together, these findings suggest that $\mathrm{PHD}_{4}, \mathrm{PHD}_{5}$, and $\mathrm{PHD}_{6}$ contribute to the total binding strength of $\mathrm{PHD}_{4-6}$.

We assessed which amino acids in $\mathrm{PHD}_{4-6}$ are critical for $\mathrm{PHD}_{4-6}$ 's binding ability using several site-specific mutations. $\mathrm{PHD}_{6}$ was chosen to introduce site-specific mutations because $\mathrm{PHD}_{4-6}$ 's binding ability was inhibited more by deletion of $\mathrm{PHD}_{6}$ than by deletion of $\mathrm{PHD}_{4}$ or $\mathrm{PHD}_{5}$ (data not shown). We mutated several amino acids that are highly conserved in $\mathrm{PHD}_{6}$ among several species (Fig. 2F; Supplemental Fig. 3G). In vitro binding assays showed that the quadruple point mutant $\mathrm{mPHD}_{4-6}$ (E1516A/E1517A/D1518A/E1544A), the double mutant W1529A/E1544A, and the mutant in the $\mathrm{C}_{4} \mathrm{HC}_{3}$ motif (C1523A) lost their binding abilities, whereas other mutants did not (Fig. 2G; Supplemental Fig. 3H). Some mutations, such as C1430R and C1471Y in $\mathrm{PHD}_{5}$ of MLL4, are associated with Kabuki syndrome (Hannibal et al. 2011). We also determined the effect of these mutations on $\mathrm{PHD}_{4-6}$ 's binding ability. In vitro binding assays showed that $\mathrm{C} 1430 \mathrm{R}$ and $\mathrm{C} 1471 \mathrm{Y}$ decreased the binding ability of $\mathrm{PHD}_{4-6}$ (Fig. $2 \mathrm{H}$; Supplemental Fig. 3I-K).

\section{PHD $_{4-6}$ of MLL4 is required for MLL4's nucleosomal} methylation activity

Because MLL4 methylates Lys 4 on histone H3, we determined the effect of $\mathrm{PHD}_{4-6}$ on in vitro MLL4-catalyzed methylation. We first generated expression plasmids encoding the following Flag-tagged MLL4 proteins: a C terminus of MLL4 with the catalytic domain SET (MLL4-C), a fusion protein composed of $\mathrm{PHD}_{4-6}$ and MLL4-C $\left(\right.$ MLL4 $\left._{\text {fusion }}\right)$, mutant MLL4 $_{\text {fusion }}\left(\right.$ mMLL4 $\left._{\text {fusion }}\right)$ bearing the quadruple point mutations, and $\mathrm{MLL}_{\text {fusion }}$ containing C1523A (Fig. 3A). We then transfected these plasmids into human embryonic kidney $293 \mathrm{~T}$ cells and purified Flag-tagged MLL4-C, MLL4 fusion, MMLL4 $_{\text {fusion, }}$ and MLL4 fusion (C1523A) by anti-Flag immunoprecipitation, followed by in vitro methyltransferase assays. Western blot analysis of immunoprecipitation eluates showed that all of these purified MLL4 fusion proteins equally interacted with MLL4's other core components, such as ASH2L, RBBP5, and WDR5, suggesting that the mutations do not affect the interaction between MLL4-C and other components (Supplemental Fig. 4A).

For in vitro methyltransferase assays, we first used mononucleosomes and recombinant nucleosomes as substrates because these nucleosomes better represent in vivo substrates. MLL $4_{\text {fusion }}$ had robust methyltransferase activity (Fig. 3B,C), whereas MLL4-C had undetectable nucleosomal methylation activity. Interestingly, $\mathrm{MMLL}_{\text {fusion }}$ and $M L L 4_{\text {fusion }}(\mathrm{C} 1523 \mathrm{~A})$, which contain binding mutations in $\mathrm{PHD}_{4-6}$, had negligible activities (Fig. 3B,C). We next determined whether MLL4-C, MLL4 $4_{\text {fusion, }} \operatorname{mMLL}_{\text {fusion, }}$ and MLL4 $_{\text {fusion }}(\mathrm{C} 1523 \mathrm{~A}$ ) methylate recombinant histone $\mathrm{H} 3$ and recombinant histone octamers. The methyltransferase assays showed that all of them appeared to have comparable enzymatic activities toward these nonphysiological substrates (Fig. 3C). Therefore, these results suggest that MLL4-mediated methylation of nucleosomal $\mathrm{H} 3$ tails requires the binding of $\mathrm{PHD}_{4-6}$ to $\mathrm{H} 4$ tails so that the catalytic domain SET is readily accessible to $\mathrm{H} 3$ tails. Moreover, they indicate that in addition to a region containing the SET domain, $\mathrm{PHD}_{4-6}$ is critical for MLL4-catalyzed nucleosomal methylation.

Because the Kabuki syndrome mutants C1430R and $\mathrm{C} 1471 \mathrm{Y}$ decreased the binding strength of $\mathrm{PHD}_{4-6}$, we examined the effect of C1430R and C1471Y on the enzymatic activity of MLL4 $4_{\text {fusion. }}$. Although these mutations did not affect the interaction of MLL4-C with ASH2L, RBBP5, and WDR5, they drastically abrogated the nucleosomal methylation activity of MLL4 $_{\text {fusion }}$ (Fig. 3B,C; Supplemental Fig. 4B). Similar to other MLL4 $4_{\text {fusion }}$ mutants, the C1471Y mutant also methylated recombinant histone $\mathrm{H} 3$ and histone octamers. These results implicate that mutations in $\mathrm{PHD}_{4-6}$ may contribute to Kabuki syndrome by reducing MLL4catalyzed nucleosomal methylation activities.

\section{$\mathrm{PHD}_{4-6}$ of MLL4 is indispensable for MLL4-mediated cellular differentiation}

Because our in vitro methyltransferase assays showed that MLL4 $_{\text {fusion }}$ had robust nucleosomal methylation activity (Fig. 3B,C), we determined whether ectopic expression of MLL4 $_{\text {fusion }}$ rescues decreased levels of HOXA1-3 and NESTIN mRNA during RA treatment of MLL4-depleted cells. MLL4 $4_{\text {fusion, }}$ its mutant, and green fluorescent protein (GFP) were expressed in MLL4depleted NT2/D1 cells by transient transfection (Supplemental Fig. 5A). Only MLL4 $4_{\text {fusion }}$ restored expression levels of the HOXA1-3 and NESTIN genes during RAinduced differentiation (Fig. 3D; Supplemental Fig. 5B,C). Interestingly, MLL4 $4_{\text {fusion }}$ had no significant effect on NANOG expression, indicating its specific effect on the HOXA1-3 and NESTIN genes (Fig. 3D). Consistent with the rescue results of gene expression, MLL $4_{\text {fusion }}$ almost completely rescued defective differentiation of MLL4 knockdown cells, whereas its mutant and GFP did not (Fig. 3E; Supplemental Fig. 5D). These results indicate that $\mathrm{PHD}_{4-6}$ is essential for MLL4-mediated transcriptional activation and RA-induced morphological changes of NT2/D1 cells.

\section{PRMT7 but not PRMT5 impedes MLL4 target gene expression and cellular differentiation}

Our finding that the in vitro interaction between $\mathrm{PHD}_{4-6}$ and the $\mathrm{H} 4$ tail is inhibited by H4R3me2s (Fig. 2C) led us to reason that MLL4 target genes are down-regulated by PRMTs that regulate H4R3me2s levels. PRMT5 catalyzes H4R3me2s (Bedford and Clarke 2009), and PRMT7 regu- 
Dhar et al.

A
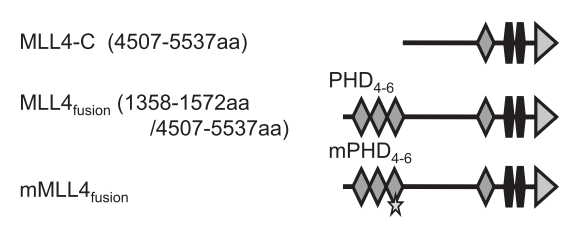

B

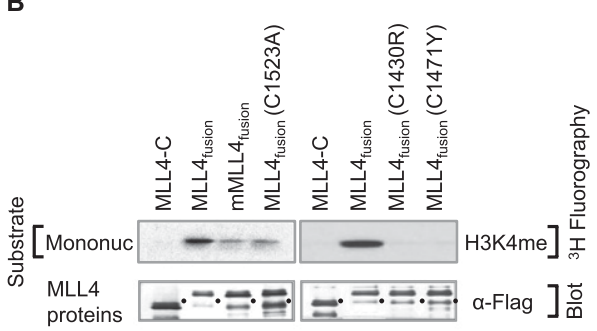

D
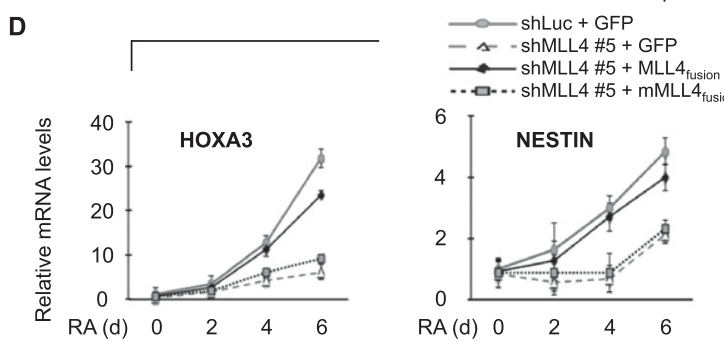

shLuc + GFP

E

Od

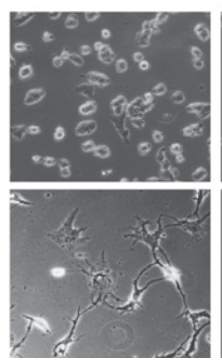

C

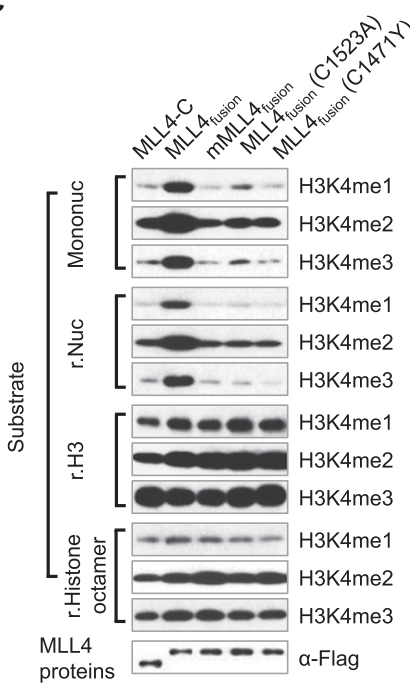

Figure 3. $\mathrm{PHD}_{4-6}$ is essential for MLL4's nucleosomal methylation activity and neuronal differentiation of NT2/D1 cells. (A) Schematic representation of MLL4-C, MLL4 $4_{\text {fusion, }}$ and $\mathrm{mMLL}_{\text {fusion. }}$ Stars indicate the quadruple mutations in $\mathrm{PHD}_{6} .(B)$ Comparison of histone methyltransferase (HMT) activities of MLL4-C, MLL4 $_{\text {fusion, }} \mathrm{mMLL}_{\text {fusion, }} \mathrm{MLL}_{\text {fusion }}$ (C1523A), $\mathrm{MLL}_{\text {fusion }}(\mathrm{C} 1430 \mathrm{R})$, and $\mathrm{MLL}_{\text {fusion }}(\mathrm{C} 1471 \mathrm{Y})$. Mononucleosomes (Mononuc) and ${ }^{3} \mathrm{H}$-labeled S-adenosyl-L-methionine were used as substrate and cofactor, respectively. Black dots indicate breakdowns. $(C)$ Comparison of HMT activities of MLL4-C, MLL4 $4_{\text {fusion, }}$ mMLL4 $_{\text {fusion, }}$ $\mathrm{MLL}_{\text {fusion }}$ (C1523A), and MLL4 $_{\text {fusion }}$ (C1471Y) by Western blot analysis. Mononucleosomes, recombinant (r.) nucleosomes (Nuc), recombinant histone $\mathrm{H} 3(\mathrm{H} 3)$, and recombinant histone octamers were used as substrates. $(D)$ Analysis of HOXA3, NESTIN, and NANOG mRNA levels by qRT-PCR after ectopic expression of $M L L 4_{\text {fusion, }}$ mMLL4 $4_{\text {fusion, }}$ or GFP. MLL4 knockdown cells (shMLL4 \#5) were transfected with expression plasmids encoding Flag-tagged GFP, Flag-tagged MLL4 $_{\text {fusion, }}$ or Flag-tagged mMLL $4_{\text {fusion, }}$ which are represented by shMLL4 \#5 + GFP, shMLL4 \#5 + MLL4 fusion, or shMLL4 \#5 + mMLL4 $_{\text {fusion, }}$ respectively. As a control, shLuciferase-treated cells were transfected with an expression plasmid encoding Flag-tagged GFP (shLuc + GFP). Two days later, these cells were treated with $10 \mu \mathrm{M}$ RA and harvested at the indicated time points. Data are presented as the mean \pm SEM (error bars) of at least three independent experiments. (E) Analysis of differentiation phenotypes after ectopic expression of GFP in shLuc-treated cells and of GFP, MLL4 $4_{\text {fusion, }}$ or mMLL $4_{\text {fusion }}$ in shMLL4 \#5-treated cells. Four different groups of cells $\left(2 \times 10^{4}\right.$ to $\left.5 \times 10^{4}\right)$ were seeded and treated with $10 \mu \mathrm{M}$ RA for 0 and $6 \mathrm{~d}$. Cell differentiation patterns were monitored using a microscope $(40 \times)$; shown are representative images of three independent experiments.

lates H4R3me2s levels either directly (Lee et al. 2005; Jelinic et al. 2006) or indirectly via the production of H4R3me1 (Zurita-Lopez et al. 2012). To determine which PRMT regulates MLL4 target genes, we assessed the effect of PRMT5 or PRMT7 knockdown on MLL4 target gene expression. PRMT5 knockdown did not increase expression levels of the HOXA1-3 and NESTIN genes, while having an inconsistent effect on their expression levels (Fig. 4A; Supplemental Fig. 6A,B). In line with this, ChIP results showed that PRMT5 depletion had no significant effect on H4R3me2s and PRMT7 levels at the MLL4 target genes (Supplemental Fig. 6C-F). In contrast, PRMT7 depletion accelerated RA-induced neuronal differentiation (Fig. 4B,C) and stimulated RAinduced transcriptional activation of the MLL4 target genes (Fig. 4D). These results indicate that PRMT7, but not PRMT5, negatively regulates the MLL4 target genes and cellular differentiation.
PRMT7-regulated H4R3me2s opposes MLL4-catalyzed H3K4 methylation at several differentiation-specific genes

Because H4R3me2s-regulating PRMT7 repressed activation of MLL4 target genes, we assessed whether PRMT7 antagonizes chromatin levels of MLL4 and H3K4me3 at MLL4 target genes. We measured the effect of PRMT7 knockdown on MLL4 and H3K4me3 levels at the HOXA1-3 and NESTIN genes by qChIP experiments. PRMT7 depletion increased MLL4 and H3K4me3 levels but decreased H4R3me2s and H4R3me1 levels at these genes at $4 \mathrm{~d}$ after RA treatment (Fig. 5A-D; Supplemental Fig. 7A-D). However, PRMT7 knockdown had no significant effect on PRMT5 levels (Supplemental Fig. 7A-D), suggesting that PRMT5 does not contribute to changes in H4R3me2s. Because $\mathrm{PHD}_{4-6}$ of MLL4 interacted with H4R3me2a, we also determined the effect of PRMT7 
A
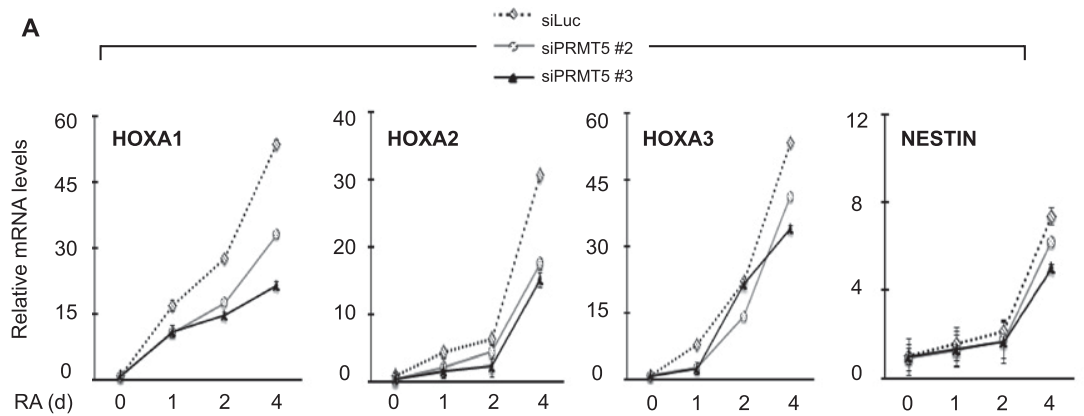

B

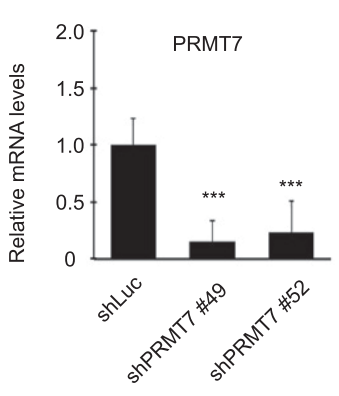

C

od
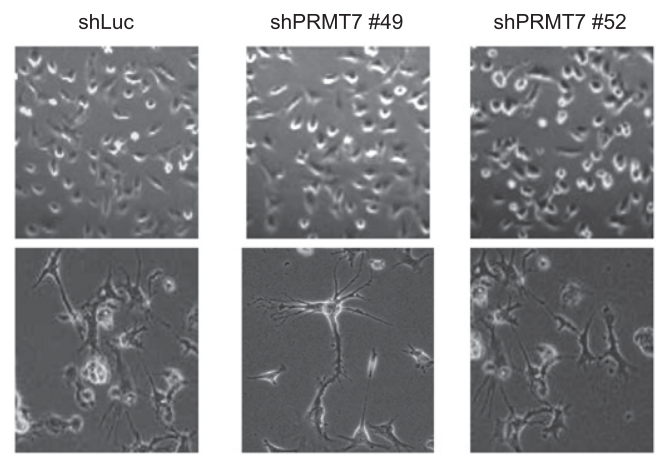

D
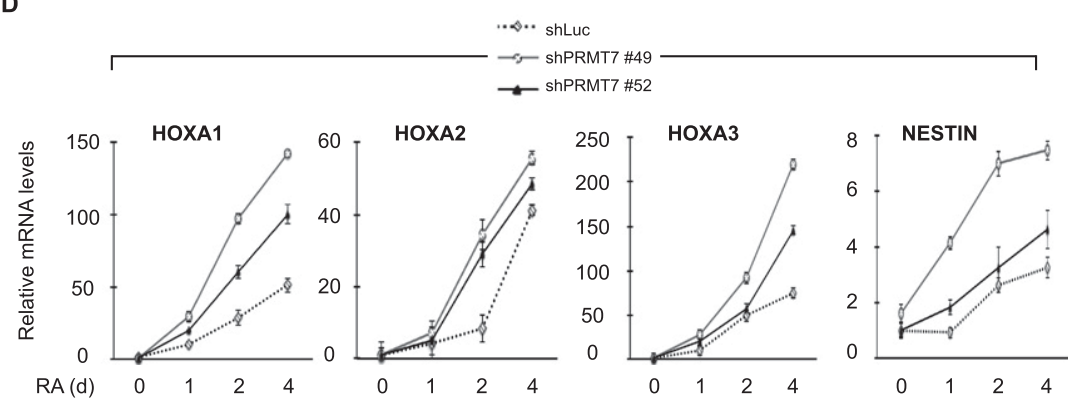

Figure 4. Knockdown of PRMT7 but not PRMT5 enhances neuronal differentiation. (A) Effect of PRMT5 knockdown on HOXA1-3 and NESTIN expression levels. NT2/D1 cells were treated with siLuciferase, siPRMT5 \#2, or siPRMT5 \#3. For neuronal differentiation, siRNA-treated cells were seeded and incubated with $10 \mu \mathrm{M}$ RA for 0-4 d. Total RNAs were isolated and analyzed by qRT-PCR. Expression levels were normalized to 18s RNA, and the relative fold change represents expression levels in individual samples over those in shLuctreated samples $(0 \mathrm{~d}) .(B)$ Analysis of PRMT7 mRNA levels by qRT-PCR after shRNAmediated knockdown of PRMT7 (shPRMT7 \#49 or shPRMT7 \#52). $\left(^{\star \star \star}\right) P<0.001$, statistically significant changes as compared with shLuc. $(C)$ Effect of PRMT7 knockdown on differentiation phenotypes after RA treatment. (D) Effect of PRMT7 knockdown on HOXA1-3 and NESTIN expression levels. Experiments were performed as in Figure 1. Data are presented as the mean \pm SEM (error bars) of at least three independent experiments. depletion on H4R3me2a levels. PRMT7 knockdown increased H4R3me2a levels like MLL4 levels. Although PRMT7 specifically regulated H4R3me2s levels at MLL4 target genes, PRMT7 knockdown had no significant effect on global H4R3me2s levels (Supplemental Fig. 7E). Consistent with the binding characteristics of $\mathrm{PHD}_{4-6}$, these results indicate that PRMT7-regulated H4R3me2s may negatively affect MLL4-catalyzed H3K4me3 by inhibiting $\mathrm{PHD}_{4-6}$ 's binding ability at MLL4 target genes.

To assess whether increased $\mathrm{H} 3 \mathrm{~K} 4 \mathrm{me} 3$ levels by PRMT7 knockdown are dependent on MLL4, we depleted both MLL4 and PRMT7 in NT2/D1 cells and compared H3K4me3 levels at MLL4 target genes between double knockdown cells and PRMT7-depleted cells (Supplemental Fig. 8A,B). ChIP experiments showed that at the HOXA1-3 and NESTIN genes, H3K4me3 levels in doubleknockdown cells were lower than those in PRMT7depleted cells and became similar to those in control cells (shLuciferase-treated cells) (Supplemental Fig. 8C-F). Consistently, double knockdown delayed cellular dif- ferentiation (Supplemental Fig. 9A) and reduced expression levels of HOXA1-3 and NESTIN but not NANOG (Supplemental Fig. 9B-F), as compared with PRMT7 depletion alone. These results indicate that H3K4me3 levels at these genes are regulated largely by MLL4, ensuring that PRMT7-regulated H4R3me2s antagonizes MLL4-catalyzed H3K4me3 at MLL4 target genes.

In addition, we determined the effect of MLL4 knockdown on PRMT7 and H4R3me2s levels at the HOXA1-3 and NESTIN genes. MLL4 knockdown delayed RA-induced decreases in H4R3me2s and PRMT7 levels at $4 \mathrm{~d}$ after RA treatment (Fig. 6A-D). We also determined the effect of MLL4 depletion on chromatin levels of H4R3me2a and the H4R3me2a methyltransferase PRMT1 at the MLL4 target genes. MLL4 knockdown impeded RAinduced increases in H4R3me2a and PRMT1 levels at the MLL4 target genes at $4 \mathrm{~d}$ (Fig. 6A-D). These results indicate that MLL4 has an antagonistic relationship with H4R3me2s but a positive association with H4R3me2a levels. 
Dhar et al.

A

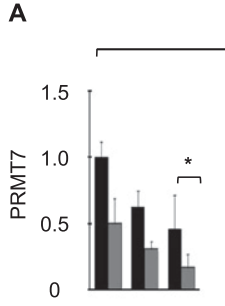

RA (d) $\begin{array}{llll}0 & 2 & 4\end{array}$

B

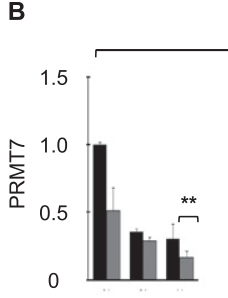

RA (d) $\quad 0 \quad 2 \quad 4$
HOXA1

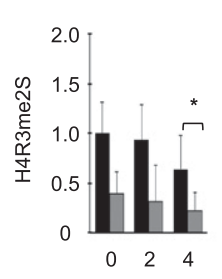

shLuc

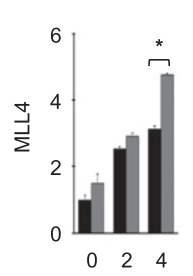

shPRMT7 \#49

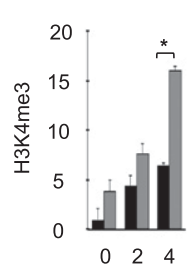

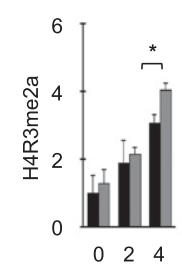

- shLuc $\square$ shPRMT7\#49

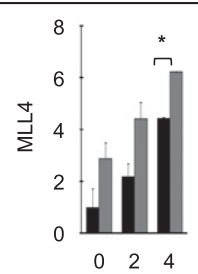

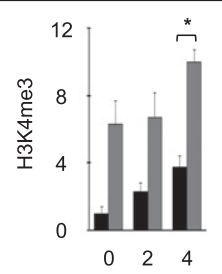

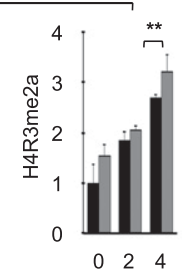

Figure 5. PRMT7 knockdown results in increased H3K4me3 and MLL4 levels at MLL4 target genes. $(A-D)$ Effect of PRMT7 knockdown on the promoter occupancy of PRMT7, H4R3me2s, MLL4, H3K4me3, and H4R3me2a at the HOXA1 $(A)$, HOXA2 $(B)$, HOXA3 $(C)$, and NESTIN $(D)$ genes during RA-induced differentiation of NT2/D1 cells. Chromatin levels of PRMT7, H4R3me2s, MLL4, H3K4me3, and H4R3me2a were analyzed by qChIP assay after incubating shLuc- or shPRMT7 \#49-treated cells with $10 \mu \mathrm{M}$ RA for 0,2 , and $4 \mathrm{~d}$. Rabbit IgG was used as a control for the ChIP assay, and PCR values for each time point were normalized to input. The relative occupancy represents the fold changes over the shLuc control $(0 \mathrm{~d})$. Data are presented as the mean \pm SEM (error bars) of at least three independent experiments. $\left(^{\star}\right) P<0.05 ;\left(^{\star \star}\right) P<0.01{ }^{*}\left(^{\star \star}\right)$ $P<0.001$, statistically significant changes.
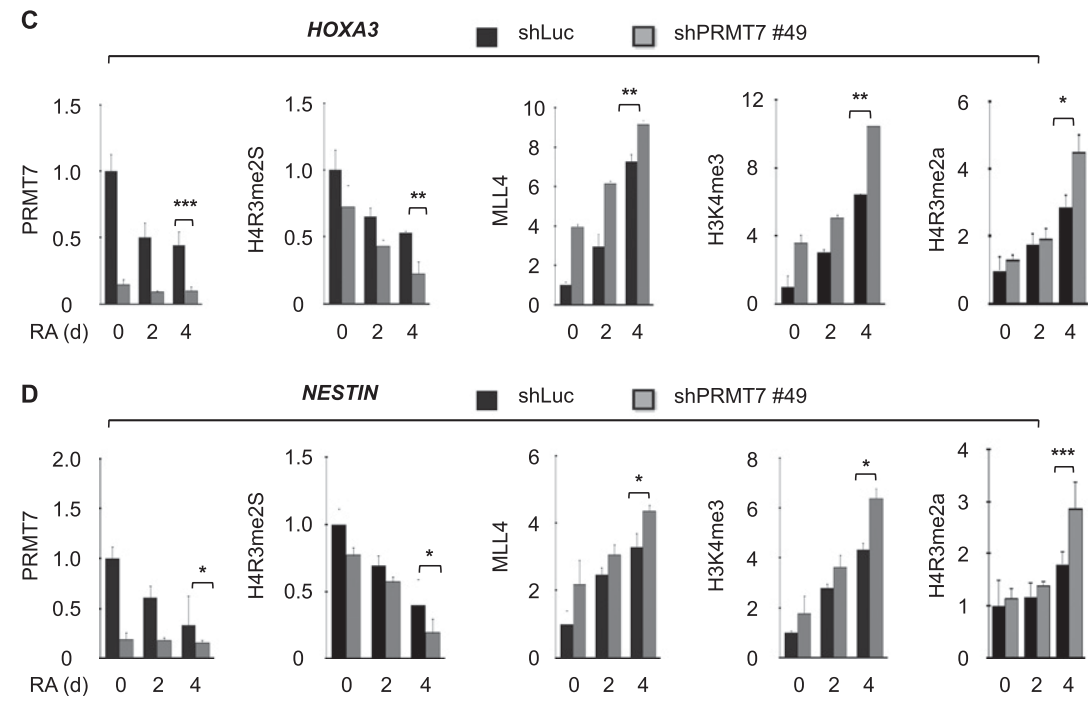

H4R3me2s levels are inversely associated with H3K4me3 levels at an array of genes, including many HOXA and HOXB cluster genes

In addition to HOXA1-3 and NESTIN, other HOX cluster genes are activated during RA-induced differentiation of NT2/D1 cells (Simeone et al. 1990; Houldsworth et al. 2002). To assess whether an antagonistic relationship exists between MLL4-catalyzed H3K4me3 and PRMT7-regulated H4R3me2s at other HOX genes, we determined MLL4, H3K4me3, PRMT7, and H4R3me2s levels at other HOXA and $H O X B$ genes in wild-type NT2/D1 cells using qChIP. MLL4 was recruited to many other $H O X$ genes, including HOXA4-7, HOXA9, HOXB1-5, and HOXB7-9, at $4 \mathrm{~d}$ after RA treatment, besides HOXA1-3 and NESTIN (Fig. 7A-C). Moreover, increased MLL4 and H3K4me3 occupancy paralleled decreased H4R3me2s and PRMT7 levels during RAinduced differentiation (Fig. 7A-C). In contrast, PRMT5 levels were not altered at most $H O X A$ and $H O X B$ genes (Fig. 7A-B), and MLL4, H3K4me3, H4R3me2s, and PRMT7 levels were not changed at the GAPDH gene (Fig. 7D).
To confirm an inverse association between H4R3me2s and MLL4-deposited H3K4me3, we analyzed the effect of PRMT7 knockdown on MLL4, H3K4me3, and H4R3me2s levels at the HOXA4-7, HOXA9, and several HOXB cluster genes, which are targeted by MLL4. Similar to the above results for the HOXA1-3 and NESTIN genes (see Fig. 5), PRMT7 knockdown increased MLL4 and H3K4me3 levels but decreased H4R3me2s levels at the HOXA4-7, HOXA9, HOXB1-5, and HOXB7-9 genes at 4 d (Supplemental Figs. 10A-E, 11A-I). These results further support a countercorrelation between $\mathrm{H} 3 \mathrm{~K} 4 \mathrm{me} 3$ and H4R3me2s and are in line with the idea that PRMT7regulated H4R3me2s opposes MLL4-mediated gene activation and cellular differentiation by counteracting MLL4catalyzed H3K4me3.

\section{Discussion}

In the present study, we describe an essential role for MLL4 in the cellular differentiation of NT2/D1 stem 
A

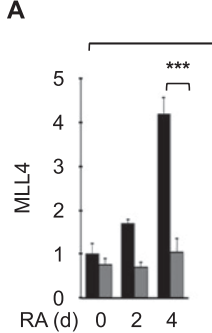

HOXA1

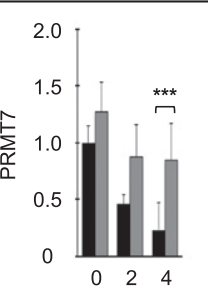

a shLuc

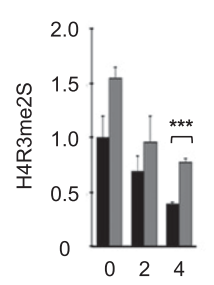

ㅁ ShMLL4 \#5

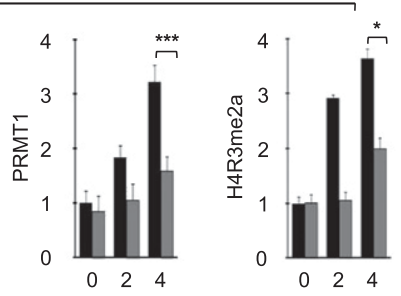

B

HOXA2
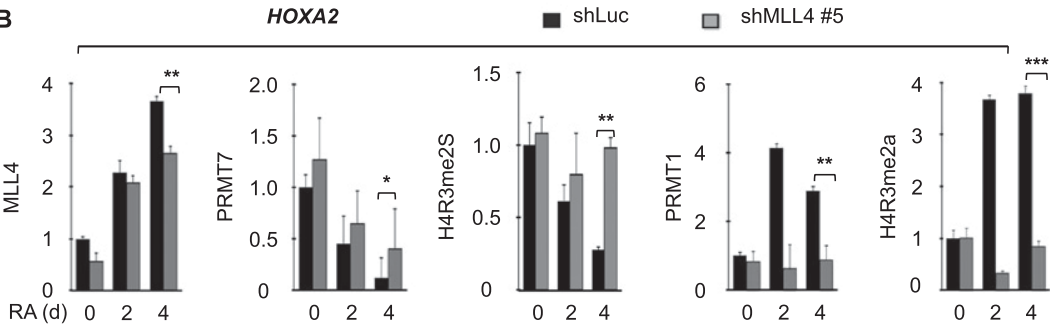

C

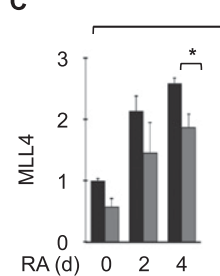

HOXA3

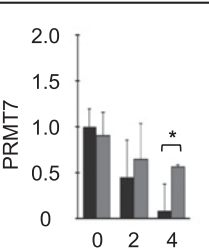

a shLuc

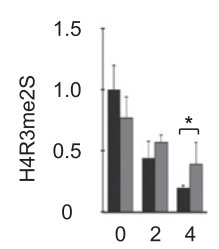

ㅁ ShMLL4 \#5

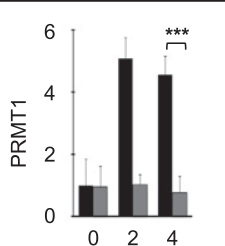

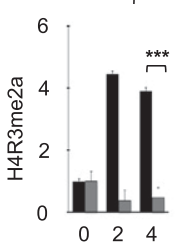

a shLuc

D

NESTIN
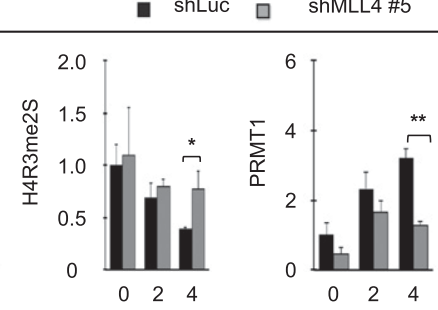

$R A(d) \quad 0 \quad 2 \quad 4$

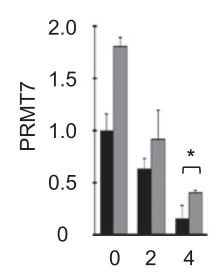

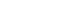

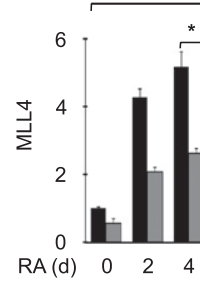

cells. Specifically, our results indicate that MLL4 mediates cellular differentiation of stem cells by depositing $\mathrm{H} 3 \mathrm{~K} 4 \mathrm{me} 3$ at a set of differentiation-specific genes and consequently activating the same genes. Moreover, our in vitro findings revealed that $\mathrm{PHD}_{4-6}$ 's binding ability to $\mathrm{H} 4 \mathrm{R} 3 \mathrm{me} 0$ and $\mathrm{H} 4 \mathrm{R} 3 \mathrm{me} 2 \mathrm{a}$ is inhibited by the repressive mark H4R3me2s. These in vitro results are in agreement with ChIP results showing that decreased H4R3me2s levels by PRMT7 knockdown increase chromatin levels of MLL4 and H3K4me3 at several MLL4 target genes. Thus, our findings indicate that the inhibition of $\mathrm{PHD}_{4-6}$ 's binding ability by H4R3me2s results in the antagonistic effect of PRMT7-regulated H4R3me2s on MLL4-catalyzed $\mathrm{H} 3 \mathrm{~K} 4 \mathrm{me} 3$ at MLL4 target genes. Interestingly, this antagonistic regulation occurs in a "trans-tail" mode in which symmetric dimethylation at arginine in the "H4 tail" (H4R3me2s) suppresses trimethylation at lysine in the "H3 tail" (H3K4me3) (Fig. 7E).

Our results revealed that at many differentiationspecific genes during cellular differentiation, decreased PRMT7 levels are accompanied by increased MLL4

Figure 6. MLL4 depletion increases PRMT7 and H4R3me2s levels and decreases PRMT1 and H4R3me2a levels at MLL4 target genes. $(A-D)$ Effect of MLL4 knockdown on the promoter occupancy of MLL4, PRMT7, H4R3me2s, PRMT1, and H4R3me2a at the HOXA1 $(A)$ HOXA2 (B), HOXA3 $(C)$, and NESTIN $(D)$ genes during RA-induced differentiation of NT2/D1 cells. Chromatin levels of MLL4, PRMT7, H4R3me2s, PRMT1, and H4R3me2a were analyzed by qChIP assay after incubating shLuc- or shMLL4 \#5-treated cells with $10 \mu \mathrm{M}$ RA for 0, 2, and $4 \mathrm{~d}$. MLL4 figures in Figure 1, G and $\mathrm{H}$, and Supplemental Figure 1, B and C, are presented again for direct comparison. Rabbit IgG was used as a control for the ChIP assay, and PCR values for each time point were normalized to input. The relative occupancy represents the fold changes over the shLuc control $(0 \mathrm{~d})$. Data are presented as the mean \pm SEM (error bars) of at least three independent experiments. $\left(^{*}\right) P<$ $\left.0.05 ;\left.\right|^{\star \star}\right) P<0.01 ;\left(^{\star \star \star}\right) P<0.001$, statistically significant changes. levels (Fig. 7). In addition, we found that in contrast to MLL4, PRMT7 repressed several MLL4 target genes and suppressed cellular differentiation. Furthermore, our double-knockdown experiments followed by ChIP indicate that increased H3K4me3 levels and gene activation by PRMT7 knockdown are compromised by MLL4 knockdown (Supplemental Figs. 8, 9). These findings indicate that PRMT7 may play a role in stem cell maintenance and suggest that MLL4 and PRMT7 play opposing roles in differentiation of NT2/D1 cells by positively and negatively regulating a nearly identical set of differentiationspecific genes, respectively.

Recent studies have shown that PRMT6-regulated H3R2me2a inhibits MLL1-catalyzed (or SET1-catalyzed) H3K4 methylation by blocking the binding of the MLL1 (or SET1) complex to the same H3 tail (Guccione et al. 2007; Kirmizis et al. 2007). Distinct from these studies, our results indicate that MLL4-deposited H3K4me3 is suppressed by PRMT7-regulated H4R3me2s in a transtail fashion. Interestingly, PRMT5-driven H4R3me2s has been shown to contribute to gene repression of the 
Dhar et al.

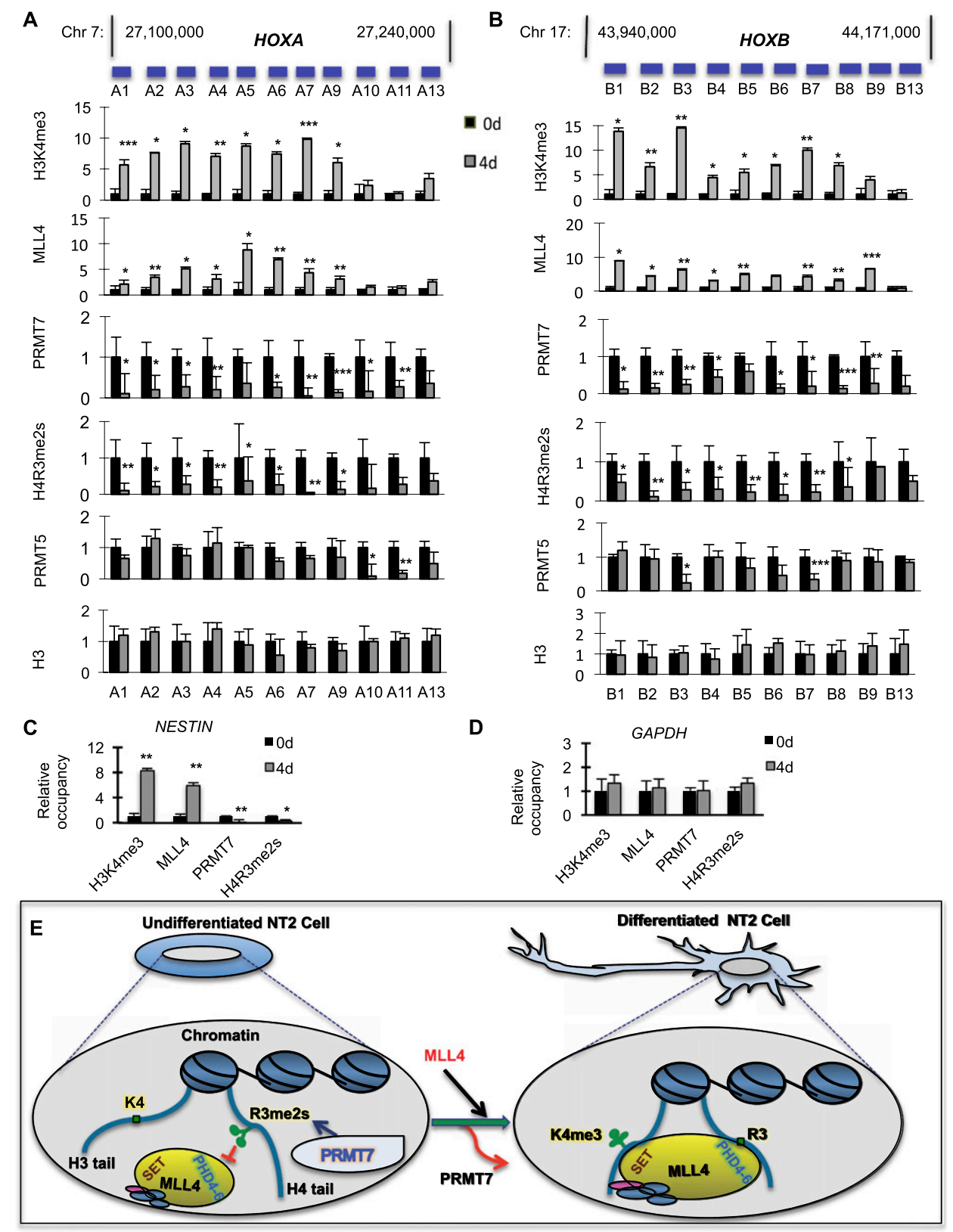

Figure 7. MLL4-catalyzed H3K4me3 levels inversely correlate with PRMT7-regulated H4R3me2s levels at most $H O X A$ and $H O X B$ cluster genes. $(A, B)$ The promoter occupancy of H3K4me3, MLL4, PRMT7, H4R3me2s, PRMT5, and H3 at the HOXA cluster $(A)$ and HOXB cluster $(B)$ genes during RA-induced differentiation of NT2/D1 cells. Chromatin levels of H3K4me3, MLL4, PRMT7, H4R3me2s, PRMT5, and H3 were analyzed by qChIP assay after treating NT2/D1 cells with RA for $0 \mathrm{~d}$ and $4 \mathrm{~d}$. H3 was used as a control for ChIP assay, and PCR values for each time point were normalized to input. $(C, D)$ The promoter occupancy of H3K4me3, MLL4, PRMT7, and H4R3me2s at the NESTIN $(C)$ and GAPDH $(D)$ genes. The relative occupancy represents the fold changes over 0 d. Data are presented as the mean \pm SEM (error bars). $\left(^{\star}\right) P<0.05 ;\left(^{\star \star}\right) P<0.01 ;\left(^{\star \star \star}\right) P<0.001$, statistically significant changes as compared with untreated NT2/D1 cells. (E) A proposed model in which MLL4 functions as a trans-tail reader/writer. During RAinduced differentiation, PRMT7-regulated H4R3me2s levels are decreased. Subsequently, the PHD $4-6$ domain of MLL4 recognizes (reads) H4R3me0 (or H4R3me2a) and couples MLL4's methyltransferase (writing) activity to H3K4 to generate H3K4me3. In this model, MLL4 has a "reader" function for the H4 tail and a "writer" role for the H3 tail. Therefore, MLL4 acts as a trans-tail reader/writer.

$\beta$-globin locus by recruiting the DNA methyltransferase DNMT3A (Zhao et al. 2009). However, our findings indicate that PRMT7 but not PRMT5 regulates H4R3me2s at most HOXA and HOXB cluster genes.
Therefore, although both PRMT7 and PRMT5 regulate H4R3me2s levels, they may repress the expression of different sets of genes. Thus, the inhibitory trans-tail regulation of $\mathrm{H} 3 \mathrm{~K} 4 \mathrm{me} 3$ by H4R3me2s may represent 
a previously unidentified epigenetic mechanism that underlies opposing impacts of MLL4 and PRMT7 on cellular differentiation.

PHDs bind to methylated or unmethylated lysine. For example, BHC80-PHD interacts with $\mathrm{H} 3 \mathrm{~K} 4 \mathrm{me0}$, whereas BPTF-PHD binds to H3K4me3 (Li et al. 2006; Lan et al. 2007). Intriguingly, our data demonstrated that $\mathrm{PHD}_{4-6}$ of MLL4 interacts with both H4R3me0 and H4R3me2a, suggesting plasticity in its binding activity. It is not rare that binding modules may associate with more than one mark. In fact, several biochemical and structural studies have indicated that the WD40-containing protein WDR5 interacts with H3R2me0, H3R2me2s, or H3K4me2 (Wysocka et al. 2005; Couture et al. 2006; Han et al. 2006; Schuetz et al. 2006; Migliori et al. 2012). Therefore, the binding pocket of $\mathrm{PHD}_{4-6}$ may be spatially arranged to accommodate both marks, although future structural studies may reveal a detailed binding mechanism. The interaction between the tandem PHD and H4R $3 \mathrm{me} 0 / \mathrm{me} 2 \mathrm{a}$ appears to be specific because it is inhibited by H4R3me2s. Interestingly, our data revealed that individual PHDs in $\mathrm{PHD}_{4-6}$ of MLL4 possess a similar binding property toward H4R3me0/me2a, suggesting that the three PHDs in $\mathrm{PHD}_{4-6}$ recognize three $\mathrm{H} 4$ tails on nucleosomes.

Our ChIP results showed that increased $\mathrm{H} 4 \mathrm{R} 3 \mathrm{me} 2 \mathrm{a}$ levels coincided with MLL4 recruitment at many HOXA and $H O X B$ genes. In addition, PRMT7 knockdown simultaneously increased H4R3me2a and MLL4 levels at many MLL4 target genes, and MLL4 knockdown decreased H4R3me2a levels. These results are consistent with in vitro interaction of $\mathrm{PHD}_{4-6}$ with $\mathrm{H} 4 \mathrm{R} 3 \mathrm{me} 2 \mathrm{a}$ and indicate that H4R3me2a is involved in MLL4 recruitment.

In vitro methylation assays revealed that MLL4's $\mathrm{PHD}_{4-6}$ is important for the H3K4 nucleosomal methylation activity of MLL4. In addition, our data from the rescue experiments suggest that $\mathrm{PHD}_{4-6}$ of MLL4 is required for the expression of differentiation-specific genes and the morphological changes during the lineage commitment of NT2/D1 cells. Together, these findings indicate that $\mathrm{PHD}_{4-6}$ of MLL4 is a new type of epigenetic module that likely contributes to cellular memory by mediating the establishment of H3K4me3 at MLL4 target genes and subsequently affecting gene expression during cellular differentiation.

$\mathrm{PHD}_{4-6}$ 's binding ability and MLL4's enzymatic activity were decreased by clinical mutations in Kabuki syndrome patients. These findings indicate that loss-offunction mutations of MLL4's $\mathrm{PHD}_{4-6}$ in Kabuki syndrome may affect disease status by inhibiting MLL4mediated differentiation. In addition to Kabuki syndrome, insertion and deletion mutations of the $M L L 4$ gene frequently occur in medulloblastoma and nonHodgkin lymphomas (Morin et al. 2011; Parsons et al. 2011; Pasqualucci et al. 2011). In this regard, loss-offunction mutations of the $M L L 4$ gene may block cellular differentiation processing in these diseases, perhaps contributing to cancer phenotypes. Therefore, our findings may be relevant to an epigenetic understanding of the molecular pathogenesis of medulloblastoma and non-
Hodgkin lymphomas. We found high sequence identities between $\mathrm{PHD}_{4-6}$ of MLL4 and its corresponding tandem PHD of MLL3 (Supplemental Fig. 12), suggesting that the tandem PHD in MLL3 possesses binding characteristics similar to those of MLL4. It has also been reported that $M L L 3$ undergoes genetic aberrations in medulloblastoma like MLL4 (Parsons et al. 2011). Therefore, our findings on MLL4 may be applicable to future studies of the pathogenic role of MLL3 mutations.

\section{Materials and methods}

Antibodies, plasmids, and cell lines

Anti-MLL2/MLL4 (ab32474) and anti-H4R3me2s (ab5823) were purchased from Abcam. Anti-MLL2/MLL4 (AP6183a) was from Abgent. Anti-PRMT5 (07-405) and anti-H3K4me3 (07-473) were from Millipore. Anti-Flag mouse monoclonal M2 (F3165) and anti- $\beta$-Actin (A5441) were from Sigma. Anti-MLL2/MLL4 (H-300, sc-292359), anti-PRMT7 (H-300, sc-98882), and anti-GST (z-5, sc-459) were from Santa Cruz Biotechnology. Anti-PRMT1 (2449S) was from Cell Signaling Technologies. Anti-H4R3me2a (39705/39706) was from Active Motif. Anti-H4R3me1 (NB212011SS) was from Novus Biologics.

The bacterial expression plasmids encoding the PHD domains of MLL4 ( $\mathrm{PHD}_{1-3}$, amino acids $156-341 ; \mathrm{PHD}_{4-6}$, amino acids $1358-$ 1572; $\mathrm{PHD}_{4}$, amino acids $1358-1442 ; \mathrm{PHD}_{5}$, amino acids 1414 1492; $\mathrm{PHD}_{6}$, amino acids 1486-1572; and $\mathrm{PHD}_{7}$, amino acids 50795152; NCBI GenBank protein accession no. NP_003473.3) were constructed using the pGEX6P-1 vector (Amersham Biosciences). The bacterial expression plasmids harboring mutations in $\mathrm{PHD}_{4-6}$ (E1516A/E1517A/D1518A/E1544A [called PPHD $_{4-6}$ ], P1508A, Y1514A, W1529A, C1523A, W1529A/E1544A, C1430R, and $\mathrm{C} 1471 \mathrm{Y}$ ) were generated by site-directed mutagenesis according to the manufacturer's instructions (Stratagene). For expression in mammalian cells, the cDNAs encoding MLL4-C, MLL4 $_{\text {fusion, }}$ and mMLL4 $4_{\text {fusion }}$ were cloned into the pFlag-CMV2 vector (Sigma).

The NT2/D1 embryonic carcinoma cell line was maintained in DMEM supplemented with $10 \%$ fetal bovine serum (FBS). Cells were treated with $10 \mu \mathrm{M}$ All trans-RA to induce differentiation.

Purification of bacterial recombinant proteins

GST-tagged PHD domains of MLL4 were expressed in Escherichia coli BL21 (DE3) (Stratagene), which were cultured in LB medium (50 $\mu \mathrm{M}$ IPTG) for $14-16 \mathrm{~h}$ at $16^{\circ} \mathrm{C}$. Bacterial cells were pelleted, resuspended in the lysis buffer $(20 \mathrm{mM}$ Tris- $\mathrm{HCl}$ at $\mathrm{pH} 8.0$, $137 \mathrm{mM} \mathrm{NaCl}, 1.5 \mathrm{mM} \mathrm{MgCl} 2,1 \mathrm{mM}$ EDTA, $0.2 \mathrm{mM}$ phenylmethylsulfonyl fluoride [PMSF], 10\% [v/v] glycerol) and lysed with lysozyme of a concentration of $0.5 \mathrm{mg} / \mathrm{mL}$ for $1 \mathrm{~h}$ at $4^{\circ} \mathrm{C}$. Cells were further lysed by sonication, and the supernatants were collected after centrifugation. The whole-cell lysates were incubated with glutathione beads for $14-16 \mathrm{~h}$ at $4^{\circ} \mathrm{C}$ (Amersham), followed by extensive washing with lysis buffer supplemented with $0.1 \%$ Triton X-100. The GST fusion proteins were eluted with the glutathione-containing elution buffer (100 mM Tris- $\mathrm{HCl}$ at $\mathrm{pH} 8.0)$.

\section{Peptide pull-down assays}

Biotinylated peptides $(0.2-1 \mu \mathrm{g})$ were incubated with $2 \mu \mathrm{g}$ of recombinant proteins in $300 \mu \mathrm{L}$ of binding buffer $(50 \mathrm{mM}$ Tris- 
$\mathrm{HCl}$ at $\mathrm{pH} 7.5,300 \mathrm{mM} \mathrm{NaCl}, 0.1 \%[\mathrm{v} / \mathrm{v}]$ Nonidet P-40, $1 \mathrm{mM}$ PMSF, $1 \mu \mathrm{g} / \mathrm{mL}$ aprotinin, $2.5 \mu \mathrm{g} / \mathrm{mL}$ leupeptin, $1 \mu \mathrm{g} / \mathrm{mL}$ pepstatin at $\mathrm{pH} 8.0$ ) for $14-16 \mathrm{~h}$ at $4^{\circ} \mathrm{C}$. After $1 \mathrm{~h}$ of incubation, streptavidin beads (Amersham Biosciences) were washed four times and eluted using $1 \times$ SDS-PAGE sample buffer $162.5 \mathrm{mM}$ Tris, $5 \% \quad \beta$-mercaptoethanol, $2 \%$ SDS, $10 \%$ glycerol, $0.01 \%$ Bromophenol blue at $\mathrm{pH}$ 6.8). Eluates were examined by Western blot analysis.

\section{Immunoprecipitation}

To express MLL4-C, MLL4 $4_{\text {fusion, }}$ and MLL4 $4_{\text {fusion }}$ mutants, human embryonic kidney 293T cells were transfected with pFlag-CMV2 plasmids harboring cDNA of MLL4-C, MLL4 $4_{\text {fusion, }}$ mMLL4 $4_{\text {fusion, }}$ or $\mathrm{MLL}_{\text {fusion }}(\mathrm{C} 1523 \mathrm{~A})$. Cells were disrupted using lysis buffer (20 mM Tris- $\mathrm{HCl}, 137 \mathrm{mM} \mathrm{NaCl}, 1.5 \mathrm{mM} \mathrm{MgCl}, 1 \mathrm{mM}$ EDTA, $10 \%$ glycerol, $1 \%$ Triton X-100, $0.2 \mathrm{mM}$ PMSF, $1 \mu \mathrm{g} / \mathrm{mL}$ aprotinin, $2.5 \mu \mathrm{g} / \mathrm{mL}$ leupeptin, $1 \mu \mathrm{g} / \mathrm{mL}$ pepstatin at $\mathrm{pH} 8.0)$. Anti-Flag M2 affinity resin (Sigma) was incubated with wholecell lysates, followed by extensive washing with BC500 $(20 \mathrm{mM}$ Tris- $\mathrm{HCl}, 500 \mathrm{mM} \mathrm{KCl}, 1.5 \mathrm{mM} \mathrm{MgCl} 2,0.2 \mathrm{mM}$ EDTA, $10 \%$ glycerol, $0.2 \mathrm{mM}$ PMSF, $1 \mu \mathrm{g} / \mathrm{mL}$ aprotinin, $2.5 \mu \mathrm{g} / \mathrm{mL}$ leupeptin, $1 \mu \mathrm{g} / \mathrm{mL}$ pepstatin at $\mathrm{pH} 8.0$ ) containing $0.1 \%$ NP40. Immunoprecipitation using anti-Flag resin was performed as previously described (Lee et al. 2007). The Flag-tagged proteins were eluted by a histone methyltransferase (HMT) buffer $(50 \mathrm{mM}$ Tris- $\mathrm{HCl}$, $100 \mathrm{mM} \mathrm{KCl}, 5 \mathrm{mM} \mathrm{MgCl} 2,10 \%$ glycerol at $\mathrm{pH} 8.5$ ) supplemented with $0.4 \mu \mathrm{g} / \mathrm{mL}$ Flag peptide. The amounts of recombinant proteins were compared by Western blot analysis.

\section{HMT assay}

All assays were performed in HMT buffer $(50 \mathrm{mM}$ Tris-HCl, 100 $\mathrm{mM} \mathrm{KCl}, 5 \mathrm{mM} \mathrm{MgCl}_{2}, 4 \mathrm{mM}$ DTT, $10 \%$ glycerol at $\mathrm{pH} 8.5$ ) as previously described (Nishioka and Reinberg 2003). Briefly, MLL4-C, MLL4 $4_{\text {fusion, }}$ and mMLL4 $4_{\text {fusion }}$ proteins were incubated with $1 \mu \mathrm{g}$ of substrate (mononucleosomes, recombinant nucleosomes, recombinant $\mathrm{H} 3$, and histone octamers) for $4 \mathrm{~h}$ at $30^{\circ} \mathrm{C}$ in $15 \mu \mathrm{L}$ of a final volume of HMT buffer containing $2.5 \mu \mathrm{M}$ ${ }^{3} \mathrm{H}$-labeled S-adenosyl-L-methionine $\left(\left[{ }^{3} \mathrm{H}\right] \mathrm{SAM}\right)$ or $80 \mu \mathrm{M}$ SAM (New England Biolabs). The reaction was stopped by $2 \times$ SDS sample buffer, and then the proteins were separated on a $4 \%-$ $20 \%$ Tris-glycine gel (Invitrogen).

\section{ChIP assay}

ChIP assays were performed using the Millipore ChIP protocol with minor modifications. NT2/D1 cells were fixed with $1 \%$ formaldehyde and lysed with lysis buffer $(50 \mathrm{mM}$ Tris at $\mathrm{pH} 8.0$, $10 \mathrm{mM}$ EDTA, 1\% SDS, $0.2 \mathrm{mM}$ PMSF, $1 \mu \mathrm{g} / \mathrm{mL}$ aprotinin, $2.5 \mu \mathrm{g} / \mathrm{mL}$ leupeptin, $1 \mu \mathrm{g} / \mathrm{mL}$ pepstatin). The cell lysates were sonicated with a Bioruptor machine (Diagenode) for 12-18 min with cycles of 30-sec pulses and 1-min pauses to shear the DNA to a final size of $200-500 \mathrm{bp}$. After preclearing with protein A beads (Repligen) for $1-2 \mathrm{~h}$, the antibody was added and incubated overnight at $4^{\circ} \mathrm{C}$. Protein A-agarose beads were added and incubated for 1-2 h. The complex was washed with low-salt buffer, high-salt buffer, and LiCl buffer and twice with TE buffer, followed by elution in a buffer containing $1 \%$ SDS and $0.1 \mathrm{M}$ $\mathrm{NaHCO}_{3}$. The cross-links were reversed, and the DNA was purified with a QIAquick PCR purification kit (Qiagen) and subjected to analysis by quantitative real-time PCR. Chromatin immunoprecipitates for proteins and methyl marks were amplified by quantitative PCR (qPCR), normalized to input, and calculated as percentage of input. Relative occupancy represents the fold change in percentage of input over the control (e.g., shMLL4 \#5/shLuc), and enrichment levels indicate the fold change over IgG control. The PCR primer and shRNA sequences are available on request. Data are presented as the mean \pm SEM.

\section{RNAi and NT2/D1 cell differentiation}

For lentivirus-mediated infection, 293T cells were transfected with shMLL4 \#5, shMLL4 \#10, shPRMT7 \#49, shPRMT7 \#52, or control shRNA (shLuc) that were purchased from Sigma. These shRNA plasmids, which contain a puromycin-resistant marker, were cotransfected along with a packing plasmid (deltaR8) and an envelope plasmid (VSV-G) into 293T cells using a calcium phosphate method. Thirteen hours later, the medium was replaced with DMEM supplemented with 10\% FBS. Virus particles containing shMLL4, shPRMT5, shPRMT7, or shLuc were generated for $2 \mathrm{~d}$ and used to infect NT2/D1 mammalian cells. NT2/D1 cells were infected for $2 \mathrm{~d}$ using virus-containing medium, and the infected cells were selected in medium containing $2.5 \mu \mathrm{g} / \mathrm{mL}$ puromycin for $2 \mathrm{~d}$.

For siRNA-mediated knockdown, siRNAs against PRMT5 and PRMT7 were purchased from Integrated DNA Technologies (IDT). The selected siRNA sequences were as follows: siPRMT5 \#2, 5'-GGACUGGAAUACGCUAAUUGUGGGA-3'; siPRMT5 \#3, 5'-GCCACCAAUCUAUGAAGACCUCAGG-3'; and siPRMT7, 5'-GGACCGUGCUGAAGCCAGACAGCGU-3'. As controls, siRNA against Luciferase GL3 RNA (5'-AACTTACGCTGAG TACTTCGA-dTdT-3') from Dharmacon was used. Cells $(5 \times$ $10^{4}$ ) in a six-well plate were transfected with siRNAs at a final concentration of $100 \mathrm{nM}$ using Lipofectamine RNAiMAX (Invitrogen) for 48 to $96 \mathrm{~h}$ of incubation.

For double knockdown, shMLL4 \#5, siPRMT7, or control shRNA (shLuc) were used. MLL4 knockdown cells $\left(2 \times 10^{5}\right.$ to $5 \times 10^{5}$ cells) were seeded in $60-\mathrm{mm}$ dishes and, $24 \mathrm{~h}$ later, were transfected with siRNA PRMT7 at a final concentration of $100 \mathrm{nM}$ using Lipofectamine RNAiMAX. Two days later, these cells were treated with $10 \mu \mathrm{M}$ RA for 4 and $6 \mathrm{~d}$ and harvested at the indicated time points for ChIP assays. Total RNAs were isolated and analyzed by qRT-PCR.

Knockdown efficiency was examined by Western blot analysis and qRT-PCR. Knockdown cells were treated with $10 \mu$ M RA for 0-6 d, monitored for cell differentiation patterns, and harvested for further analysis. Whole-cell extracts from shRNA-treated cells were prepared using a mammalian lysis buffer $(20 \mathrm{mM}$ Tris, $137 \mathrm{mM} \mathrm{NaCl}, 1.5 \mathrm{mM} \mathrm{MgCl} 2,1 \mathrm{mM}$ EDTA, 10\% glycerol, $1 \%$ Triton $\mathrm{X}-100$ at $\mathrm{pH} 8.0$ ), subjected to $3 \%-8 \%$ Tris acetate gel electrophoresis or $8 \%-10 \%$ SDS-PAGE, and electrophoretically transferred onto polyvinylidene difluoride membranes (Millipore). Blots were treated with primary antibodies and secondary antibodies (anti-rabbit or anti-mouse AP conjugate; Promega). The protein bands were visualized by incubating membranes in AP buffer containing $165 \mu \mathrm{g} / \mathrm{mL}$ BCIP and $330 \mu \mathrm{g} / \mathrm{mL}$ NBT.

Rescue experiments by ectopic expression of $M L L 4_{\text {fusion }}$ proteins

Knockdown cells $\left(2 \times 10^{5}\right.$ to $5 \times 10^{5}$ cells $)$ were seeded in 60 -mm dishes and, $24 \mathrm{~h}$ later, were transfected with $4 \mu \mathrm{g}$ of pFlagCMV2 expression plasmids encoding the $\mathrm{MLL}_{\text {fusion }}$ construct $\left(\mathrm{PHD}_{4-6}+\mathrm{C}\right), \mathrm{mMLL}_{\text {fusion, }}$ or GFP using $12 \mu \mathrm{L}$ of Fugene 6 (Roche). Two days later, these cells were treated with $10 \mu \mathrm{M}$ RA for $6 \mathrm{~d}$ and harvested at the indicated time points for further analysis. Total RNAs were isolated and analyzed by qRT-PCR. 
RNA isolation, $c D N A$ synthesis, and $q R T-P C R$

Total RNAs were isolated using RNeasy kits (Qiagen) according to the manufacturer's instructions. cDNA was synthesized using the iScript cDNA synthesis kit (Bio-Rad) according to the manufacturer's instructions and amplified with iQ SYBR Green Supermix (Bio-Rad) using the CFX384 real-time PCR detection system (Bio-Rad). Expression levels were quantified using CFX Manager software and were normalized to 18s RNA, and the relative mRNA level represents the fold change over the control. Data are presented as the mean \pm SEM (error bars). Where indicated, statistical $P$-values were determined using Student's $t$-test.

\section{Statistical analysis}

The statistical significance between the two groups was analyzed by Student's $t$-test. $P<0.05\left({ }^{\star}\right), P<0.01\left(^{\star \star}\right)$, and $P<0.001$ $\left({ }^{\star \star \star}\right)$ indicate statistically significant changes.

\section{Acknowledgments}

We are grateful to Drs. Dinshaw Patel and Zhanxin Wang for their isothermal titration calorimetry assays, Dr. Mark Bedford for his peptides, and Ms. Ann Sutton for assistance in manuscript editing. This work was supported by grants to M.G.L. from the NIH (R01 GM095659, R01 CA157919, and CCSG 5 P30 CA0166672 35) and Cancer Prevention and Research Institute of Texas (RP110183), a scholar fellowship to S.S.D. from the Center for Cancer Epigenetics at M.D. Anderson Cancer Center, fellowships to P.V. from the Deutsche Akademie der Naturforscher Leopoldina (LPDS 2009-5) and the Empire State Training Program in Stem Cell Research (NYSTEM, contract no. C026880), and grants to D.R. from the Howard Hughes Medical Institute and the NIH (GM064844 and R37GM037120).

\section{References}

Adam MP, Hudgins L. 2005. Kabuki syndrome: A review. Clin Genet 67: 209-219.

Barski A, Cuddapah S, Cui K, Roh TY, Schones DE, Wang Z, Wei G, Chepelev I, Zhao K. 2007. High-resolution profiling of histone methylations in the human genome. Cell 129: 823-837.

Bedford MT, Clarke SG. 2009. Protein arginine methylation in mammals: Who, what, and why. Mol Cell 33: 1-13.

Bernstein BE, Kamal M, Lindblad-Toh K, Bekiranov S, Bailey DK, Huebert DJ, McMahon S, Karlsson EK, Kulbokas EJ 3rd, Gingeras TR, et al. 2005. Genomic maps and comparative analysis of histone modifications in human and mouse. Cell 120: 169-181.

Cho YW, Hong T, Hong S, Guo H, Yu H, Kim D, Guszczynski T, Dressler GR, Copeland TD, Kalkum M, et al. 2007. PTIP associates with MLL3- and MLL4-containing histone $\mathrm{H} 3$ lysine 4 methyltransferase complex. I Biol Chem 282: 20395-20406.

Couture JF, Collazo E, Trievel RC. 2006. Molecular recognition of histone $\mathrm{H} 3$ by the WD40 protein WDR5. Nat Struct Mol Biol 13: 698-703.

Guccione E, Bassi C, Casadio F, Martinato F, Cesaroni M, Schuchlautz H, Luscher B, Amati B. 2007. Methylation of histone H3R2 by PRMT6 and H3K4 by an MLL complex are mutually exclusive. Nature 449: 933-937.

Guenther MG, Levine SS, Boyer LA, Jaenisch R, Young RA. 2007. A chromatin landmark and transcription initiation at most promoters in human cells. Cell 130: 77-88.
Han Z, Guo L, Wang H, Shen Y, Deng XW, Chai J. 2006. Structural basis for the specific recognition of methylated histone $\mathrm{H} 3$ lysine 4 by the WD-40 protein WDR5. Mol Cell 22: 137-144.

Hannibal MC, Buckingham KJ, Ng SB, Ming JE, Beck AE, McMillin MJ, Gildersleeve HI, Bigham AW, Tabor HK, Mefford HC, et al. 2011. Spectrum of MLL2 (ALR) mutations in 110 cases of Kabuki syndrome. Am J Med Genet A 155A: $1511-1516$

Heintzman ND, Hon GC, Hawkins RD, Kheradpour P, Stark A, Harp LF, Ye Z, Lee LK, Stuart RK, Ching CW, et al. 2009. Histone modifications at human enhancers reflect global cell-type-specific gene expression. Nature 459: 108-112.

Houldsworth J, Heath SC, Bosl GJ, Studer L, Chaganti RS. 2002. Expression profiling of lineage differentiation in pluripotential human embryonal carcinoma cells. Cell Growth Differ 13: 257-264.

Issaeva I, Zonis $\mathrm{Y}$, Rozovskaia $\mathrm{T}$, Orlovsky $\mathrm{K}$, Croce CM, Nakamura T, Mazo A, Eisenbach L, Canaani E. 2007. Knockdown of ALR (MLL2) reveals ALR target genes and leads to alterations in cell adhesion and growth. Mol Cell Biol 27: 1889-1903.

Jelinic P, Stehle JC, Shaw P. 2006. The testis-specific factor CTCFL cooperates with the protein methyltransferase PRMT7 in H19 imprinting control region methylation. PLOS Biol 4: e355. doi: 10.1371/journal.pbio.0040355.

Kirmizis A, Santos-Rosa H, Penkett CJ, Singer MA, Vermeulen M, Mann M, Bahler J, Green RD, Kouzarides T. 2007. Arginine methylation at histone H3R2 controls deposition of H3K4 trimethylation. Nature 449: 928-932.

Kornberg RD, Lorch Y. 1999. Twenty-five years of the nucleosome, fundamental particle of the eukaryote chromosome. Cell 98: 285-294.

Lan F, Collins RE, De Cegli R, Alpatov R, Horton JR, Shi X, Gozani O, Cheng X, Shi Y. 2007. Recognition of unmethylated histone H3 lysine 4 links BHC80 to LSD1-mediated gene repression. Nature 448: 718-722.

Lange M, Kaynak B, Forster UB, Tonjes M, Fischer JJ, Grimm C, Schlesinger J, Just S, Dunkel I, Krueger T, et al. 2008. Regulation of muscle development by DPF3, a novel histone acetylation and methylation reader of the BAF chromatin remodeling complex. Genes Dev 22: 2370-2384.

Lee JH, Cook JR, Yang ZH, Mirochnitchenko O, Gunderson SI, Felix AM, Herth N, Hoffmann R, Pestka S. 2005. PRMT7, a new protein arginine methyltransferase that synthesizes symmetric dimethylarginine. I Biol Chem 280: 36563664.

Lee MG, Villa R, Trojer P, Norman J, Yan KP, Reinberg D, Di Croce L, Shiekhattar R. 2007. Demethylation of H3K27 regulates polycomb recruitment and $\mathrm{H} 2 \mathrm{~A}$ ubiquitination. Science 318: 447-450.

Li H, Ilin S, Wang W, Duncan EM, Wysocka J, Allis CD, Patel DJ. 2006. Molecular basis for site-specific read-out of histone H3K4me3 by the BPTF PHD finger of NURF. Nature 442: 91-95.

Martin C, Zhang Y. 2005. The diverse functions of histone lysine methylation. Natl Rev 6: 838-849.

Migliori V, Muller J, Phalke S, Low D, Bezzi M, Mok WC, Sahu SK, Gunaratne J, Capasso P, Bassi C, et al. 2012. Symmetric dimethylation of H3R2 is a newly identified histone mark that supports euchromatin maintenance. Nat Struct Mol Biol 19: 136-144.

Morin RD, Mendez-Lago M, Mungall AJ, Goya R, Mungall KL, Corbett RD, Johnson NA, Severson TM, Chiu R, Field M, et al. 2011. Frequent mutation of histone-modifying genes in non-Hodgkin lymphoma. Nature 476: 298-303. 
Musselman CA, Kutateladze TG. 2011. Handpicking epigenetic marks with PHD fingers. Nucleic Acids Res 39: 9061-9071.

Musselman CA, Ramirez J, Sims JK, Mansfield RE, Oliver SS, Denu JM, Mackay JP, Wade PA, Hagman J, Kutateladze TG. 2012. Bivalent recognition of nucleosomes by the tandem PHD fingers of the CHD4 ATPase is required for CHD4mediated repression. Proc Natl Acad Sci 109: 787-792.

$\mathrm{Ng} \mathrm{SB}$, Bigham AW, Buckingham KJ, Hannibal MC, McMillin MJ, Gildersleeve HI, Beck AE, Tabor HK, Cooper GM, Mefford HC, et al. 2010. Exome sequencing identifies MLL2 mutations as a cause of Kabuki syndrome. Nat Genet 42: 790-793.

Nishioka K, Reinberg D. 2003. Methods and tips for the purification of human histone methyltransferases. Methods 31: 49-58.

Pan G, Tian S, Nie J, Yang C, Ruotti V, Wei H, Jonsdottir GA, Stewart R, Thomson JA. 2007. Whole-genome analysis of histone H3 lysine 4 and lysine 27 methylation in human embryonic stem cells. Cell Stem Cell 1: 299-312.

Parsons DW, Li M, Zhang X, Jones S, Leary RJ, Lin JC, Boca SM, Carter H, Samayoa J, Bettegowda C, et al. 2011. The genetic landscape of the childhood cancer medulloblastoma. Science 331: 435-439.

Pasqualucci L, Trifonov V, Fabbri G, Ma J, Rossi D, Chiarenza A, Wells VA, Grunn A, Messina M, Elliot O, et al. 2011 Analysis of the coding genome of diffuse large B-cell lymphoma. Nat Genet 43: 830-837.

Pena PV, Davrazou F, Shi X, Walter KL, Verkhusha VV, Gozani O, Zhao R, Kutateladze TG. 2006. Molecular mechanism of histone H3K4me3 recognition by plant homeodomain of ING2. Nature 442: 100-103.

Pokholok DK, Harbison CT, Levine S, Cole M, Hannett NM, Lee TI, Bell GW, Walker K, Rolfe PA, Herbolsheimer E, et al. 2005. Genome-wide map of nucleosome acetylation and methylation in yeast. Cell 122: 517-527.

Roussel MF, Hatten ME. 2011. Cerebellum development and medulloblastoma. Curr Top Dev Biol 94: 235-282.

Ruthenburg AJ, Allis CD, Wysocka J. 2007. Methylation of lysine 4 on histone H3: Intricacy of writing and reading a single epigenetic mark. Mol Cell 25: 15-30.

Schuetz A, Allali-Hassani A, Martin F, Loppnau P, Vedadi M, Bochkarev A, Plotnikov AN, Arrowsmith CH, Min J. 2006. Structural basis for molecular recognition and presentation of histone H3 by WDR5. EMBO J 25: 4245-4252.

Shi X, Hong T, Walter KL, Ewalt M, Michishita E, Hung T, Carney D, Pena P, Lan F, Kaadige MR, et al. 2006. ING2 PHD domain links histone $\mathrm{H} 3$ lysine 4 methylation to active gene repression. Nature 442: 96-99.

Simeone A, Acampora D, Arcioni L, Andrews PW, Boncinelli E, Mavilio F. 1990. Sequential activation of HOX2 homeobox genes by retinoic acid in human embryonal carcinoma cells. Nature 346: 763-766.

Sims RJ 3rd, Nishioka K, Reinberg D. 2003. Histone lysine methylation: A signature for chromatin function. Trends Genet 19: 629-639.

Visel A, Blow MJ, Li Z, Zhang T, Akiyama JA, Holt A, PlajzerFrick I, Shoukry M, Wright C, Chen F, et al. 2009. ChIP-seq accurately predicts tissue-specific activity of enhancers. Nature 457: 854-858.

Weber M, Hellmann I, Stadler MB, Ramos L, Paabo S, Rebhan M, Schubeler D. 2007. Distribution, silencing potential and evolutionary impact of promoter DNA methylation in the human genome. Nat Genet 39: 457-466.

Wysocka I, Swigut T, Milne TA, Dou Y, Zhang X, Burlingame AL, Roeder RG, Brivanlou AH, Allis CD. 2005. WDR5 associates with histone $\mathrm{H} 3$ methylated at $\mathrm{K} 4$ and is essential for H3 K4 methylation and vertebrate development. Cell 121: 859-872.

Wysocka J, Swigut T, Xiao H, Milne TA, Kwon SY, Landry J, Kauer M, Tackett AJ, Chait BT, Badenhorst P, et al. 2006. A PHD finger of NURF couples histone $\mathrm{H} 3$ lysine 4 trimethylation with chromatin remodelling. Nature 442: 86-90.

Zeng L, Zhang Q, Li S, Plotnikov AN, Walsh MJ, Zhou MM. 2010. Mechanism and regulation of acetylated histone binding by the tandem PHD finger of DPF3b. Nature 466: $258-262$

Zhao XD, Han X, Chew JL, Liu J, Chiu KP, Choo A, Orlov YL, Sung WK, Shahab A, Kuznetsov VA, et al. 2007. Wholegenome mapping of histone $\mathrm{H} 3$ Lys4 and 27 trimethylations reveals distinct genomic compartments in human embryonic stem cells. Cell Stem Cell 1: 286-298.

Zhao Q, Rank G, Tan YT, Li H, Moritz RL, Simpson RJ, Cerruti L, Curtis DJ, Patel DJ, Allis CD, et al. 2009. PRMT5mediated methylation of histone H4R3 recruits DNMT3A, coupling histone and DNA methylation in gene silencing. Nat Struct Mol Biol 16: 304-311.

Zurita-Lopez CI, Sandberg T, Kelly R, Clarke SG. 2012. Human protein arginine methyltransferase 7 (PRMT7) is a type III enzyme forming $\omega$-NG-monomethylated arginine residues. I Biol Chem 287: 7859-7870. 


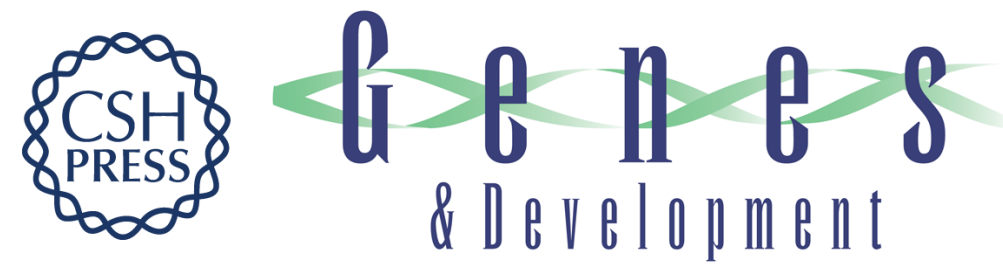

\section{Trans-tail regulation of MLL4-catalyzed H3K4 methylation by H4R3 symmetric dimethylation is mediated by a tandem PHD of MLL4}

Shilpa S. Dhar, Sung-Hun Lee, Pu-Yeh Kan, et al.

Genes Dev. 2012, 26:

Access the most recent version at doi:10.1101/gad.203356.112

Supplemental http://genesdev.cshlp.org/content/suppl/2012/12/18/26.24.2749.DC1
Material

References This article cites 47 articles, 9 of which can be accessed free at:

http://genesdev.cshlp.org/content/26/24/2749.full.html\#ref-list-1

License

Email Alerting Receive free email alerts when new articles cite this article - sign up in the box at the top

Service

right corner of the article or click here.

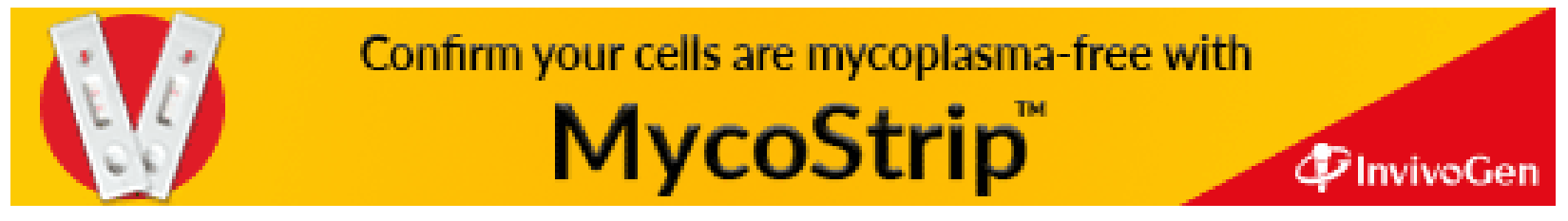

